\title{
High status diet and health in Medieval Lisbon: a combined isotopic and osteological analysis of the Islamic population from São Jorge Castle, Portugal
}

\author{
${\text { Alice } \text { Toso }^{1} \text { (D) } \cdot \text { Sara Gaspar }}^{2} \cdot$ Rodrigo Banha da Silva $^{3} \cdot$ Susana J. Garcia ${ }^{2} \cdot$ Michelle Alexander $^{1}$
}

Received: 28 March 2018 / Accepted: 11 March 2019 / Published online: 2 April 2019

(C) The Author(s) 2019

\begin{abstract}
This paper presents the first bioarchaeological study of Islamic diet and lifeways in medieval Portugal. Stable isotopes of $\delta^{13} \mathrm{C}$ and $\delta^{15} \mathrm{~N}$ and osteological and paleopathological analyses are combined to explore the diet and health status of 27 humans buried within São Jorge Castle, Lisbon (eleventh to twelfth century), interpreted as a high status population. Human isotopic data are considered alongside an animal baseline comprised of 30 specimens sampled from nearby Praça da Figueira, including the main domesticates and fish. Isotopic data indicate an age- and sex-related difference in diet among the population, suggesting a difference in food access between females and children compared to males. Palaeopathological analysis indicates a low prevalence of non-specific stress indicators such as Harris lines (HL), linear enamel hypoplasia (LEH) and cribra orbitalia (CO) in this population in comparison to other medieval populations. LEH is only present in adults. These results suggest the presence of socio-cultural patterning relating to the organisation of the Islamic family, where women and men occupied different places in the household and society. This paper demonstrates the utility of a combined osteological and isotopic approach to understand the lifeways of Islamic populations in Medieval Iberia, as well as illuminates the lifeways of understudied segments of the population.
\end{abstract}

Keywords Muslim, diet $\cdot$ Medieval, Portugal $\cdot$ Stable isotopes $\cdot$ Paleopathology

\section{Introduction}

This study applies a combination of bioarchaeological techniques to explore a human skeletal assemblage from São Jorge Castle, Lisbon, dating to the time of Islamic rule (eighth to thirteenth century). Osteological and paleopathological analysis, together with carbon $\left(\delta^{13} \mathrm{C}\right)$ and nitrogen $\left(\delta^{15} \mathrm{~N}\right)$ isotopic analysis of human and animal bone collagen are employed to explore the diet and lifeways of this high status population (Fig. 1). The standard Muslim burial custom entails the use

Alice Toso

alice.toso@york.ac.uk

1 BioArCh, Department of Archaeology, University of York, York, UK

2 CAPP, Instituto Superior de Ciências Sociais e Políticas, Museu Nacional de História Natural e da Ciência, Universidade de Lisboa, Lisbon, Portugal

3 Centro de Arqueologia de Lisboa, Lisbon, Portugal of dedicated areas for burial, usually located outside the city walls with no discrimination based on social status (Insoll 1999, p. 169). The unusual location of these interments, within the Castle itself, suggests these individuals might have had a privileged treatment at death and therefore belonged to an elevated social status, with possible links to the ruling Islamic family. The archaeological excavation and associated finds provide a chronology for the use of this site between the tenth and eleventh century, at the height of Islamic rule in Lisbon. This assemblage thus provides a unique opportunity to explore the dietary habits and overall health status of a specific group of individuals within Lisbon's Medieval Muslim community.

Isotopic research into medieval diet among Islamic populations in Iberia is growing, specifically in Spain. Research has been undertaken on individuals from Valencia and Aragon (Alexander et al. 2015; Guede et al. 2015; Salazar-García et al. 2014, 2016), a small assemblage from Granada (Jiménez-Brobeil et al. 2016) and the Balearic Islands of Mallorca (Cau Ontiveros et al. 2016; Garcia et al. 2004), 
Fig. 1 a Location of Lisbon in Portugal; b location of São Jorge Castle (human remains) and Praça da Figueira (animal remains) (adapted from Planta da cidade de Lisboa 1650, copia de Carvalho Jr. in Silva, 1884); c sites of Praça Nova (1) and Palácio das Cozinhas (2) (adapted from drawing by Rita Nobre Neto da Silva (2014) based on municipal open-source cartography Câmara Municipal de Lisboa, 2012)

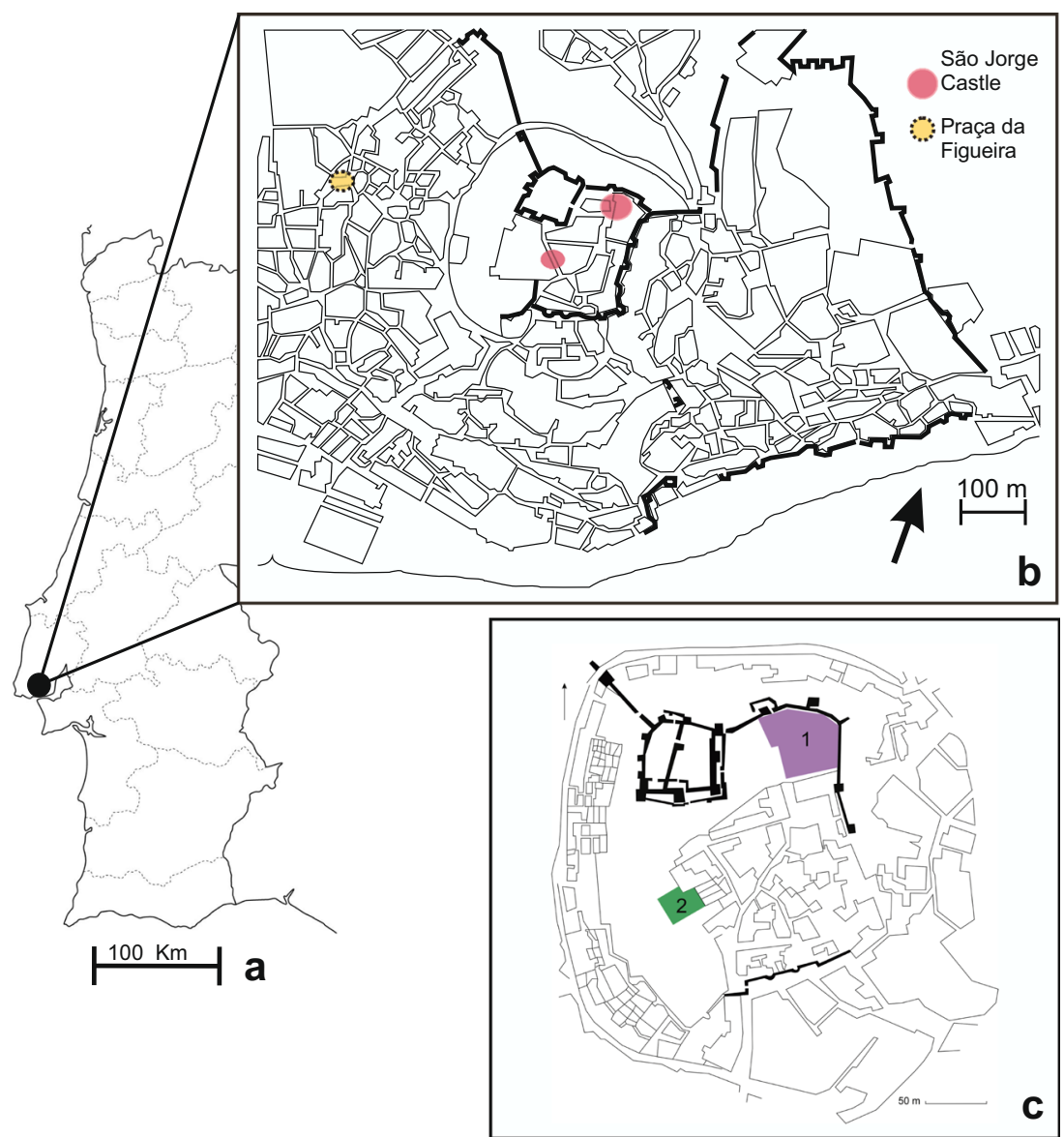

Ibiza and Formentera (Fuller et al. 2010; Nehlich et al. 2012; Pickard et al. 2017). Regarding Portuguese material, a recent article explored the diet of a group of Late Antique Christian individuals from Monte da Cegonha (Saragoça et al. 2016). However, to date no research has been published on Portuguese Islamic material.

\section{Osteology, lifeways and diet}

The combination of osteology and stable isotopes analysis offers different but complimentary data sets, which allow us to investigate medieval lifeways more holistically in terms of diet and health. Pathological alterations such as dental enamel hypoplasia, cribra orbitalia, Harris lines and periostitis are the bone/teeth insults commonly investigated in non-adults and adults in past populations. These lesions are considered signs of nonspecific stress and are used to produce an overall, but approximate idea of community health, to reconstruct the health profile of the population (Mays 2013).

This study aims to identify potential variations in dietary habits and lifeways within the Muslim social elite. Notably, this represents the first application of stable isotope analysis to examine diet for an Islamic population in
Portugal, adding a new body of data to the understanding of medieval diet on the Western edge of the Iberian Peninsula. This paper demonstrates the potential of a combined bioarchaeological approach to understand medieval lifeways, and to shed light onto specific segments of the society that were traditionally understudied or misrepresented in the historical sources (i.e. women and children).

\section{Site context}

This study is primarily focused on skeletal materials from Islamic burials from São Jorge Castle (SJC), located on a hilltop in the centre of present day Lisbon (Fig. 1). A settlement with defensive walls was established here in the Roman period (Bugalhão 2009, p. 385), commanding a strategic location at the confluence of the River Tagus and the Atlantic Ocean. The area is surrounded by fertile territory and has convenient access to the interior by river, making this site particularly appealing to Muslim settlers in 714 CE (Picard 2000 , p. 25). However, the role of Lisbon in the first years of Islamic rule was marginal until the ninth century. Its major expansion, testified by the construction of later defensive walls, took place between the eleventh and twelfth centuries 
(Torres 1994). The castle is mentioned in Christian sources that describe Lisbon immediately after the conquest; however, its foundation is yet to be attributed to a specific date. The building that stands today has undergone vast restoration and is, in fact, a Medieval Christian fortress, with later sixteenth and seventeenth century additions (Melo 2014, p. 46).

Archaeological excavation undertaken within the Castle site recovered several stratified structures pertaining to different chronologies, indicating a long-lasting occupation from the Iron Age to the post-medieval period. However, the publication of data from the excavation focuses mainly on the later medieval period under Christian rule (Gaspar and Gomes 2001; Gomes et al. 2003).

The faunal remains included in this study were excavated from the nearby site of Praça da Figueira in Lisbon. Praça da Figueira has a notable place in the history of Lisbon's archaeology. Excavations of the Modern Age Royal Hospital of All Saints between 1960 and 1971 and more recent works between 1999 and 2001 revealed a long diachronic use of the site, from a Late Bronze Age small settlement (circa 10th-9th $\mathrm{BCE}$ ) to the modern day. Late Antique/post-Roman occupation was recorded and other structures dated to the Islamic period (eleventh to twelfth century) were identified, along with later medieval activity associated with a nearby Dominican convent (thirteenth century onwards). Archaeological evidence for the seventh to mid-eleventh century is scarce but significant evidence was found for the second half of the eleventh century, consistent with agricultural use of the land. However, during the early twelfth century, a swift change occurred in the eastern part of the area where blocks of houses and roads were built. This suburban expansion attests to the enlargement of Muslim Lisbon in the few decades that preceded the Christian conquest by the coalition of Northern European Crusaders and the Portuguese king (1147 CE). Some of the excavated suburban Muslim houses were kept in use after the Christian conquest, while others were abandoned. By the early thirteenth century, only two of them were still occupied, and most of the area regained its previous agricultural vocation.

\section{Archaeological evidence for diet in Medieval lberia and Lisbon}

Much of what is known about medieval diet comes from historical accounts that usually focus on Christian Europe. While a handful of cookbooks and health treatises survived from the late medieval period concerning Islamic Spain, no information is given on the territories of modern day Portugal (Rosenberger 1999, p. 222; Adamson 2004, p. 117). Variety appears to be the basic feature of early medieval diet at all social levels; however, qualitative and quantitative differences existed between various social groups, and food played an important role in reinforcing group identities at the time (Montanari 1999, p. 169). Arab cuisine focused mostly on meat from domestic animals, fowl and game, accompanied by vegetables and a variety of flat breads in the East or semolina flour couscous in the Maghreb. Animal fat, especially from mutton, was widely used (Rosenberger 1999, p. 214). Although the principles of Arab cuisine can be generally applied to the Islamic west, the Iberian Peninsula developed its own variations due to the assimilation of previous culinary traditions, namely those imported by Phoenicians, Greeks and Romans (Adamson 2004, pp. 115-116). In the absence of specific historical sources for the Portuguese territories, archaeological research plays a crucial role in shedding light onto dietary habits and food preferences shown by the Islamic community of the West.

The use of plants in the diet of medieval Muslims and Christians, including imports, is widely documented in historical sources. Although they describe the main products consumed in Medieval Christian Portugal, these can be applied, with some approximation, to the late Islamic period. In a few cases, the link between the persistence of Islamic customs orcelery, common vervain and cumin were recorded especially in Praça D. Pedro IV with ruderal species including goosefoot, annual mercury, purslane and common nettle (Bugalhão and Queiroz 2006; Queiroz 1999; Queiroz and Mateus 2012). Surprisingly, in both Lisbon contexts, there was no trace of leguminous plants or cereals, although they are widely mentioned in historical sources (Rei 2017, pp. 70-71). This misrepresentation, especially in comparison to other Islamic sites in Southern Portugal, is linked to the nature of the sites that, especially for NARC, was linked to a possible fruit processing and transformation industry (Bugalhão and Queiroz 2006). Since stable isotope analysis of collagen cannot inform on the fruits and vegetables consumed, these findings are a valuable contribution to explore variety in the medieval diet, although in this case they do not reveal the cereal staples, which are usually found as charred cereal remains in silos.

Historical sources mention a high reliance on herbivores such as cattle, sheep and goat and also birds such as chickens and partridge (Catarino 1998, p. 126; Gonçalves 1989, p. 294). Dairy and eggs would also have been widely consumed, and were a substantial part of the protein intake of the lower classes (Catarino 1998, pp. 130-131). Wild animals like rabbits and hares were consumed by all social classes as they were very abundant in Portugal (Gonçalves 2004). Fish consumption was common (e.g. sardines and tuna): inshore and coastal fishes are an easy catch and may have supplemented the diet of the lower classes in those areas (Catarino 1998, p. 142; Gonçalves 2004). In terms of zooarchaeological evidence for diet, animal bones from five sites in Lisbon have been studied, four of 
which have been published and include material of Islamic chronology: Sé (Moreno-García and Davis 2001); São Jorge Castle (Moreno-García 2008 unpublished); NARC (Bugalhão et al. 2008; Moreno-García and Gabriel 2001); Lisbon western quarter (Bugalhão et al. 2008) and Largo da Severa (Valente and Marques 2017). Four of these sites date between the ninth to twelfth century and resulted from different waste activities in Islamic Lisbon. The consumption pattern portrayed at these sites adheres to other Islamic cities in Portugal such as Santarém (Davis 2006; Moreno-García and Davis 2001), Alcácer do Sal (Moreno-García and Davis 2001), Mértola (Antunes 1996; Morales Muñiz 1993; Moreno-García and Pimenta 2012), Mesas do Castelinho (Cardoso 1993), Évora (Costa and Lopes 2012), and Silves (Davis et al. 2008) with a predominance of sheep/goat, followed by cattle and rabbit.

Zooarchaeological studies of faunal assemblages from Islamic sites showed a high predominance of ovicaprids as the most represented species, followed by rabbit. Only two sites show different species as being the most common: pig in Torre Vedras (Gabriel 2003) and cow in Conimbriga (Detry et al. 2014). The presence of pig is quite surprising though somehow common in Islamic sites (Detry et al. 2014, p. 101). This is usually explained as pig breeding for Christian consumption or wild boar hunting, a practice that was permitted in case of need, and still exists in modern Maghreb tribes (Simoons 1961). Cattle is common and is usually the second or third most represented species across all sites. The assemblage from São Jorge Castle itself is rather small and therefore it is hard to judge how representative it is. It is interesting to note, however, that unlike other Islamic fortresses in Portugal, there is no trace of larger hunted animals such as deer that are considered a sign of high status diet and found at similar sites elsewhere, e.g. Paderne, Palmela, Salir and Sintra (Cardoso and Fernandes 2012; Coelho 2012; Fernandes et al. 2015; Martins 2013; Pereira 2013). In terms of age at death, evidence indicates that sheep/goat were slaughtered for consumption at a younger age whereas cattle were older, perhaps consumed after their agricultural use as draught animals was over, in accordance with the suggestions of Arabic culinary treatises (Nasrallah 2007).

\section{Materials}

Within São Jorge Castle, 35 individuals were excavated from two sites: Praça Nova (PN) and Palácio das Cozinhas (PC). Each individual was assessed for sex and age and the recurrence of three non-specific stress markers were recorded: linear enamel hypoplasia (LEH), Harris lines (HL) and cribra orbitalia (CO) as outlined below. Samples of 27 individuals were taken for stable isotope analysis of collagen $\delta^{13} \mathrm{C}$ and $\delta^{15} \mathrm{~N}$, with preference to more complete skeletons with wellpreserved ribs (Table 1). Five Islamic individuals excavated from Calçadinha do Tijolo (CDT), Alfama and Lisbon, were also analysed using stable isotope analysis to provide a low status comparison to the high status individuals from SJC. A full report of the excavation, dietary and anthropological study has been published elsewhere (Filipe et al. 2018).

Animal bone samples from a range of taxa $(n=38)$ were collected from waste pits associated with domestic contexts

Table 1 List of analysed individuals from São Jorge Castle (SJC)

\begin{tabular}{|c|c|c|c|c|c|c|}
\hline Individual codes & Age (y.o.) & Sex & LEH & HL & $\mathrm{CO}$ & SAI \\
\hline CSJ.PC.1 & IA & M & & & & $\mathrm{x}$ \\
\hline CSJ.PN.1 & $30-49$ & M & $\checkmark$ & & $\checkmark$ & $\checkmark$ \\
\hline CSJ.PN.2 & $18-29$ & $\mathrm{~F}$ & $\checkmark$ & & $\checkmark$ & $\checkmark$ \\
\hline CSJ.PC.2 & $18-29$ & I & & & & $\checkmark$ \\
\hline CSJ.PC.3 & $6-11$ & NA & $\checkmark$ & $\checkmark$ & $\checkmark$ & $\checkmark$ \\
\hline CSJ.PC.4 & $0.16-5$ & NA & & $\checkmark$ & & $\checkmark$ \\
\hline CSJ.PN.4 & $0.16-5$ & NA & $\checkmark$ & & & $\checkmark$ \\
\hline CSJ.PC.5 & $12-17$ & NA & $\checkmark$ & & & $\checkmark$ \\
\hline CSJ.PN.5 & $12-17$ & NA & $\checkmark$ & & & $\checkmark$ \\
\hline CSJ.PC.6 & IA & M & & & & \\
\hline CSJ.PN.6 & $0.16-5$ & NA & $\checkmark$ & $\checkmark$ & $\checkmark$ & $\checkmark$ \\
\hline CSJ.PC.7 & $18-29$ & $\mathrm{~F}$ & $\checkmark$ & & & $\checkmark$ \\
\hline CSJ.PN.7 & $0.16-5$ & NA & & & & $\checkmark$ \\
\hline CSJ.PC.8 & $18-29$ & M & $\checkmark$ & & $\checkmark$ & $\checkmark$ \\
\hline CSJ.PN.8 & $0.16-5$ & NA & $\checkmark$ & & $\checkmark$ & $\checkmark$ \\
\hline CSJ.PC.9 & IA & M & & $\checkmark$ & & \\
\hline CSJ.PN.9 & Foetus & NA & & $\checkmark$ & & \\
\hline CSJ.PN.10 & NB & NA & $\checkmark$ & & & $\checkmark$ \\
\hline CSJ.PC.11 & $12-17$ & NA & $\checkmark$ & & $\checkmark$ & $\checkmark$ \\
\hline CSJ.PN.11 & NB & NA & & & & $\checkmark$ \\
\hline CSJ.PC. 12 & $18-29$ & $\mathrm{~F}$ & & & & $\checkmark$ \\
\hline CSJ.PN.12 & NB & NA & & & & $\checkmark$ \\
\hline CSJ.PC.13 & $0.16-5$ & NA & & & $\checkmark$ & $\checkmark$ \\
\hline CSJ.PN.13 & $0.16-5$ & NA & & & & $\checkmark$ \\
\hline CSJ.PC.14 & $>50$ & $\mathrm{~F}$ & & $\checkmark$ & & $\checkmark$ \\
\hline CSJ.PN.14 & NB & NA & & $\checkmark$ & & $\checkmark$ \\
\hline CSJ.PC.15 & Foetus & NA & & $\checkmark$ & & \\
\hline CSJ.PN.15 & NB & NA & & & & $\checkmark$ \\
\hline CSJ.PC.16 & $30-49$ & $\mathrm{~F}$ & & & & $\checkmark$ \\
\hline CSJ.PC.17 & $0.17-5$ & NA & $\checkmark$ & & $\checkmark$ & $\checkmark$ \\
\hline CSJ.PC. 18 & INA & NA & & & & \\
\hline CSJ.PC.19 & $30-49$ & $\mathrm{~F}$ & & & & $\checkmark$ \\
\hline CSJ.PC. 20 & NB & NA & & $\checkmark$ & & $\checkmark$ \\
\hline CSJ.PC. 21 & IA & I & & & & \\
\hline CSJ.PC.22 & IA & $\mathrm{F}$ & & & & \\
\hline
\end{tabular}

Codes: $I$ indeterminate, $I A$ indeterminate adult, $I N A$ indeterminate nonadult, $N B$ newborn, $L E H$ linear enamel hypoplasia, $H L$ Harris lines, $C O$ cribra orbitalia, SIA stable isotopes analysis 
excavated in Praça da Figueira under the direction of Dr. Rodrigo Banha da Silva. To increase sample size, animals were sampled from layers dating from the Roman to the late medieval period (first to fourteenth centuries).

\section{Methods}

\section{Preservation, paleodemographic and paleopathological assessment}

The anatomical preservation index (API) and the bone representation index (BRI) were calculated for all individuals, following Dutour (1989) and Garcia (2005/2006), in order to assess if there were differences in preservation regarding sex and age, which could bias the demographic profile of the sample. The skeleton was divided in 44 anatomical parts classified between 0 (bone not preserved) and 1 (bone present and complete). For the vertebral column, pelvic girdle, ribs, hands and feet, a ratio between the number of preserved bones and the bones that should have been present was computed (BRI). The quality of the periosteum was not quantified.

Paleodemographic data were collected by standard methods as outlined below. Individuals were assembled in age groups according to the following categories: foetus (under 39 weeks); newborns (40 weeks to $<1$ month); infants (1 month to 5 years); children (6 to 11 years); juveniles (12 to 17 years); young adults (18 to 29 years); middle-aged adults (30 to 49 years) and old adults (> 50 years).

For non-adults, age at death was estimated primarily through dental development (Liversidge et al. 1993; Liversidge and Molleson 1999). In the absence of teeth, the length of long bones shafts and skeleton maturation were used to provide an age estimation (Cardoso 2005; Scheuer et al. 2009). Adult age estimation was performed following multiple methods such as the evaluation of the pubic symphysis (Brooks and Suchey 1990), the auricular surface (Lovejoy et al. 1985) and the sternal end of the ribs (Ïșcan et al. 1984, 1985). In younger adults, the medial epiphysis of the clavicle was analysed to provide a more specific age according to the state of fusion observed (Cardoso 2008). For sex estimation, the method proposed by Bruzek (2002) was used. In the absence of the pelvic girdle, the skull and post-cranial bones were used (Cardoso 2000; Silva 1995; Walrath et al. 2004).

Macroscopic assessment of all skeletons was undertaken by Sara Gaspar and Susana Garcia to detect abnormal bone formations that could be related to a pathological process. All bones were systematically analysed to detect signs of infectious diseases like tuberculosis or leprosy, and metabolic diseases (e.g. scurvy, osteoporosis or vitamin D deficiency) according to Ortner (2003), Matos and Santos (2006), and Matos (2009). The presence of periostitis on the anterior tibia was investigated. Caries were recorded in all erupted deciduous and permanent teeth according to Hillson (2001). The assessment of HL was performed on adults and non-adult tibiae. Data were collected by $\mathrm{x}$-ray analysis with consideration of the indications listed by Mays (1995). Distal ends of left tibiae were classified in relation to the presence/absence of HL and in reference of the total number of lines observed: (1) tibia with one line; (2) tibia with two or three lines; (3) tibia with four or more lines. The right tibia was used in the absence of the left one.

LEH is represented by a transverse line or groove across the tooth enamel (King et al. 2005) and was recorded in the anterior permanent dentition, from both adults and non-adults. Each anterior tooth was macroscopically observed under a strong light and was classified in relation to the presence/ absence of LEH and the number of lines was counted. Only teeth with dental wear less than stage 6 were analysed (Smith 1984). Individuals with two or more anterior teeth with observable defects were considered LEH positive. The codes were as follows: (1) tooth without hypoplasia; (2) tooth with one line; (3) tooth with two or more lines. Signs of haematological disorders (e.g. anaemia) were searched in all available orbits in adults and non-adults older than 6 months. Orbital lesions were classified according to Stuart-Macadam (1985) as: (1) light; (2) moderate; (3) severe.

Statistical analyses were carried out using SPSS version 20 and 22. Due to the small sample size, non-parametric tests were used to assess associations between variables. The differences in the prevalence of the stress markers between age and sex groups were assessed with $X^{2}$ test and the Yate's correction was applied.

\section{Collagen extraction and stable isotope analysis}

Ribs were sampled from each adult skeleton. In the nonadult skeletons, ribs were not always present or were fragmented; therefore, long bones such as tibia, femur and humerus were preferred. The bones were only collected if they were incomplete and whenever the antimere was present and in a good state of preservation. Collagen was extracted following a modified Longin (1971) method including an ultrafiltration step (Brown et al. 1988). The samples $(\sim 0.4 \mathrm{~g})$ were mechanically cleaned with a scalpel blade and demineralised in acid $\left(0.6 \mathrm{M} \mathrm{HCl}\right.$ at $5{ }^{\circ} \mathrm{C}$ for up to 7 days). The resulting demineralised bone was gelatinised in $\mathrm{HCl}$ at $\mathrm{pH} 3$ for $48 \mathrm{~h}$ at $80{ }^{\circ} \mathrm{C}$. The gelatinised fraction was ultrafiltered to isolate the higher molecular weight collagen $(>30 \mathrm{kDa})$ which was then frozen $\left(\sim-20{ }^{\circ} \mathrm{C}\right)$ and lyophilized. The collagen samples were analysed in duplicate using isotope ratio mass spectrometry (IRMS) with a Sercon 20-22 at the BioArCh facilities, University of York. Isotopic values are reported following standard 
practice as the ratio of the heavier isotope to the lighter one ( $\delta$ values in parts per mille, \%o) relative to internationally defined standards for carbon ${ }^{13} \mathrm{C} /{ }^{12} \mathrm{C}$ (VPDB, Vienna Pee Dee Belemnite) and nitrogen ${ }^{15} \mathrm{~N} /{ }^{14} \mathrm{~N}$ (AIR) following the equation $\left[\delta=\left(R_{\text {sample }}-R_{\text {standard }}\right) / R_{\text {standard }} \times 1000\right]$. The analytical error for $\delta^{13} \mathrm{C}$ and $\delta^{15} \mathrm{~N}$ was $\pm 0.2 \%$ as determined by analysis of internal laboratory standards coupled with every run. The accuracy of measurements was monitored using international and in-house standards with well-known isotopic composition (in-house fish gelatine: $\delta^{13} \mathrm{C}-15.5 \pm 0.1, \delta^{15} \mathrm{~N} 14.3 \pm 0.2$; cane sugar IA-R006: $\delta^{13} \mathrm{C}-11.8 \pm 0.1$; caffeine IAEA 600 : $\delta^{13} \mathrm{C}-$ $27.8 \pm 0.1, \delta^{15} \mathrm{~N} 0.8 \pm 0.1$; ammonium sulfate IAEA N2: $\delta^{15} \mathrm{~N}$ $20.4 \pm 0.2)$

Statistical analyses of the isotopic data were conducted using SPSS with $p$ values $<0.05$ considered significant. Due to the small sample size, only the nonparametric Mann-Whitney $U$ test for equal median was used to compare groups.

\section{Results}

\section{Preservation, paleodemographic and paleopathological profile}

This collection presents a moderate API; on average, $38 \%$ of the bones were present to be analysed. Non-adults were better preserved $(43 \%)$ than adults $(31 \%)$, and males $(53 \%)$ were better preserved than females $(42 \%)$.

Figure 2 illustrates the demographic profile of the population. The sample is composed of 35 individuals, 21 non-adults and 14 adults. Of the non-adults, 13 were less than 2 years at the time of death, 3 were between 2 and 6 years and 5 were older than 6 years.

The adult sample is composed of five young adults, three middle-aged adults and one old adult. The age-at-death was undetermined in five adults. Fifty percent of the adults are female $(n=7)$ and $36 \%$ are male $(n=5)$. However, sex was not estimated in two individuals due to poor preservation.

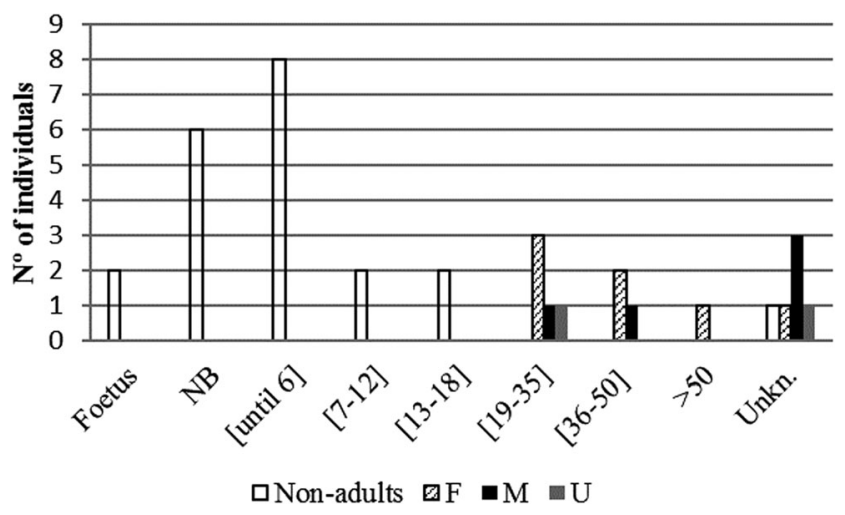

Fig. 2 Demographic profile of the population
The non-adults present more stress indicators than the adults (Table 2), although the difference is not significant $(p>0.05)$. The exception is the prevalence of LEH, which affected $33.3 \%$ of the non-adults $(n=3)$ and $75 \%$ of the adults $(n=3)$. Harris lines were scored in seven non-adults and two adults. Observable orbits included six that belonged to non-adults (older than 6 months) and three to adults. Half of the non-adults exhibit $\mathrm{CO}$, while it was absent in the adult sample.

No cases of infectious disease such as tuberculosis or leprosy were identified and no sign of non-specific osteitis or periostitis was also found. Signs of scurvy, osteoporosis or vitamin D deficiency (rickets and osteomalacia) were also not observed. From the nine non-adults with erupted permanent teeth, three exhibited caries (33\%), while in the adult population only one male individual had caries. It is worth mentioning that in the São Jorge Castle sample, only four adults have teeth preserved and ante-mortem tooth loss was not found. The sample size is too small to warrant statistical comparison.

\section{Stable isotope analysis}

All samples passed collagen quality criteria $(\% \mathrm{C}, \% \mathrm{~N}, \mathrm{C} / \mathrm{N}$; De Niro 1985; van Klinken 1999) and sufficient collagen was extracted in all samples (>1\% yield) apart from one case (CSJ.PC.20). This sample was not included in the analysis. It should be noted that the use of ultrafilters is known to substantially decrease collagen yields (Jørkov et al. 2007).

A summary of the stable isotope data including mean and standard deviation of the main species, adult and non-adult individuals is provided in Table 3 . The human and animal stable isotope data are listed in Tables 4 and 5 and plotted together in Fig. 3.

Despite the wide chronology for the animal samples, there is no chronological pattern to the data. All domestic animals exhibit a diet based on $\mathrm{C}_{3}$ plants with no trace of $\mathrm{C}_{4}$ plants.

Table 2 Prevalence of stress indicators by age and sex including LEH (linear enamel hypoplasia), HL (Harris lines), CO (cribra orbitalia)

\begin{tabular}{|c|c|c|c|c|c|c|c|c|c|c|c|c|}
\hline & \multirow{2}{*}{\multicolumn{3}{|c|}{ Non-adults }} & \multicolumn{6}{|c|}{ Adults } & \multirow{2}{*}{\multicolumn{3}{|c|}{ Total }} \\
\hline & & & & \multicolumn{3}{|c|}{ Females } & \multicolumn{3}{|c|}{ Males } & & & \\
\hline & $N$ & $n$ & $\%$ & $N$ & $n$ & $\%$ & $N$ & $n$ & $\%$ & $N$ & $n$ & $\%$ \\
\hline LEH & 9 & 3 & 33 & 2 & 1 & 50 & 2 & 2 & 100 & 12 & 6 & 50 \\
\hline HL & 7 & 1 & 14 & 1 & 0 & 0 & 1 & 0 & 0 & 9 & 1 & 11 \\
\hline $\mathrm{CO}$ & 6 & 3 & 50 & 1 & 0 & 0 & 2 & 0 & 0 & 8 & 2 & 25 \\
\hline
\end{tabular}

$N$, number of total individuals available; $n$, number of individuals with the stress markers 
Table 3 Summary of isotopic data for adults ( $>18$ years) and non-adults ( $\leq 18$ years) from São Jorge Castle (tenth to eleventh centuries) and animals from Praça da Figueira (first to fourteenth centuries)

\begin{tabular}{|c|c|c|c|c|c|c|c|c|c|}
\hline \multirow[t]{2}{*}{ Site/species } & \multirow[t]{2}{*}{$n$} & \multicolumn{4}{|c|}{$\delta^{13} \mathrm{C}_{\mathrm{VPDB}}(\% o)$} & \multicolumn{4}{|c|}{$\delta^{15} \mathrm{~N}_{\mathrm{AIR}}(\% \circ)$} \\
\hline & & Min & Max & Range & Mean $\pm 1 \sigma$ & Min & Max & Range & Mean $\pm 1 \sigma$ \\
\hline SJC adults & 10 & -19.4 & -18.5 & 0.9 & $-18.9 \pm 0.3$ & 8.6 & 11.2 & 2.6 & $9.9 \pm 0.8$ \\
\hline SJC non-adults & 17 & -18.8 & -16.5 & 2.2 & $-18.1 \pm 0.6$ & 8.4 & 13.1 & 4.3 & $10.9 \pm 1.2$ \\
\hline B. taurus (cattle) & 10 & -21.8 & -20.2 & 1.6 & $-21.1 \pm 0.5$ & 4.9 & 11.1 & 6.2 & $6.3 \pm 1.9$ \\
\hline O. aries (sheep) & 5 & -21.6 & -20.0 & 1.6 & $-20.8 \pm 0.6$ & 4.5 & 9.9 & 5.4 & $6.6 \pm 2.4$ \\
\hline C. hircus (goat) & 3 & -20.6 & -20.0 & 0.6 & $-20.2 \pm 0.6$ & 4.0 & 10.6 & 6.7 & $6.5 \pm 3.6$ \\
\hline Sus (pig/wild boar) & 6 & -21.0 & -18.9 & 2.1 & $-20.0 \pm 0.8$ & 4.9 & 7.7 & 2.8 & $6.6 \pm 1.0$ \\
\hline Gallus (chicken) & 5 & -19.9 & -18.4 & 1.4 & $-19.0 \pm 0.6$ & 8.0 & 10.7 & 2.7 & $9.4 \pm 1.3$ \\
\hline
\end{tabular}

Notably, herbivores from all periods exhibit widely ranging $\delta^{15} \mathrm{~N}$ values (4.0 to $11.1 \%$, range $7.1 \%$ ). Omnivores, as expected, have variable diets. Chickens and the one dog specimen possess similar values to humans, whereas pigs tend to have lower $\delta^{15} \mathrm{~N}$ values, placing them among the herbivores.
The trophic level offset between humans and herbivores is within the expected range of 3-5\% (Bocherens and Drucker 2003). Male values are on average $1.8 \%$ o higher in $\delta^{13} \mathrm{C}$ and $4.5 \%$ in $\delta^{15} \mathrm{~N}$ compared to the herbivores, while female values are $1.9 \%$ higher in $\delta^{13} \mathrm{C}$ and $3.1 \%$ in $\delta^{15} \mathrm{~N}$. Although males were consuming higher trophic level protein, females were
Table 4 Values of $\delta^{13} \mathrm{C}$ and $\delta^{15} \mathrm{~N}$ of the humans with indication of sex and age at death

\begin{tabular}{|c|c|c|c|c|c|c|c|}
\hline Site & Sample & Sex & Age (years) & $\delta^{13} \mathrm{C}_{\mathrm{VPDB}}(\% \circ)$ & $\delta^{15} \mathrm{~N}_{\mathrm{AIR}}(\% o)$ & $\mathrm{C} / \mathrm{N}$ & $\% \mathrm{Col}$ \\
\hline \multirow[t]{13}{*}{ Praça Nova } & 1 & M & $30-49$ & -18.8 & 11.2 & 3.23 & 0.74 \\
\hline & 2 & $\mathrm{~F}$ & $18-29$ & -18.7 & 9.4 & 3.22 & 2.91 \\
\hline & 4 & I & $0.1-5$ & -18.4 & 9.4 & 3.20 & 4.79 \\
\hline & 5 & I & $12-17$ & -17.3 & 10.4 & 3.2 & 2.52 \\
\hline & 6 & I & $0.1-5$ & -18.1 & 12.2 & 3.18 & 39.40 \\
\hline & 7 & I & $0.1-5$ & -16.5 & 11.5 & 3.27 & 2.72 \\
\hline & 8 & I & $0.1-5$ & -17.8 & 12.5 & 3.26 & 8.8 \\
\hline & 10 & I & NB & -18.7 & 10.1 & 3.22 & 1.43 \\
\hline & 11 & I & NB & -18.6 & 11.3 & 3.38 & 2.14 \\
\hline & 12 & I & NB & -17.6 & 10.4 & 3.31 & 1.23 \\
\hline & 13 & I & NB & -18.2 & 11.8 & 3.23 & 1.51 \\
\hline & 14 & I & NB & -17.8 & 11.0 & 3.18 & 3.10 \\
\hline & 15 & I & NB & -17.9 & 10.5 & 3.29 & 1.30 \\
\hline \multirow[t]{14}{*}{ Palácio das Cozinhas } & 1 & M & IA & -18.7 & 11.2 & 3.16 & 3.98 \\
\hline & 2 & I & $18-29$ & -18.8 & 9.9 & 3.29 & 0.12 \\
\hline & 3 & I & $6-11$ & -18.1 & 10.5 & 3.21 & 3.75 \\
\hline & 4 & I & $0.1-5$ & -18.2 & 10.8 & 3.20 & 4.10 \\
\hline & 5 & I & $12-17$ & -18.8 & 9.2 & 3.17 & 7.78 \\
\hline & 7 & $\mathrm{~F}$ & $18-29$ & -19.1 & 9.2 & 3.15 & 0.99 \\
\hline & 8 & M & $18-29$ & -19.4 & 10.0 & 3.22 & 1.90 \\
\hline & 11 & I & $12-17$ & -18.4 & 8.8 & 3.17 & 7.41 \\
\hline & 12 & $\mathrm{~F}$ & $18-29$ & -18.9 & 9.9 & 3.19 & 0.64 \\
\hline & 13 & I & $0.1-5$ & -17.9 & 13.1 & 3.25 & 2.96 \\
\hline & 14 & $\mathrm{~F}$ & $>50$ & -18.5 & 9.6 & 3.33 & 1.33 \\
\hline & 16 & $\mathrm{~F}$ & $30-49$ & -18.9 & 9.4 & 3.2 & 5.59 \\
\hline & 17 & I & $0.1-5$ & -18.4 & 10.9 & 3.19 & 3.56 \\
\hline & 19 & $\mathrm{~F}$ & $30-49$ & -18.9 & 8.6 & 3.21 & 1.91 \\
\hline
\end{tabular}


Table 5 Values of $\delta^{13} \mathrm{C}$ and $\delta^{15} \mathrm{~N}$ of the faunal remains (Praça da Figueira)

\begin{tabular}{|c|c|c|c|c|c|c|c|}
\hline Site & Sample & Period & Taxon & $\delta^{13} \mathrm{C}_{\mathrm{VPDB}}(\% o)$ & $\delta^{15} \mathrm{~N}_{\mathrm{AIR}}(\% o)$ & $\mathrm{C} / \mathrm{N}$ & $\% \mathrm{Col}$ \\
\hline Praça da & $8605 \mathrm{C}$ & 1 st to $3 \mathrm{rd}$ & B. taurus & -20.3 & 5.4 & 3.31 & 1.09 \\
\hline \multirow[t]{38}{*}{ Figueira } & $8584 \mathrm{C}$ & $1 \mathrm{st}$ to $3 \mathrm{rd}$ & B. taurus & -21.4 & 6.5 & 3.21 & 5.22 \\
\hline & $8521 \mathrm{C}$ & $1 \mathrm{st}$ to $3 \mathrm{rd}$ & B. taurus & -21.3 & 5.7 & 3.21 & 3.04 \\
\hline & $8204 C$ & $1 \mathrm{st}$ to $3 \mathrm{rd}$ & B. taurus & -21.5 & 5.0 & 3.18 & 4.51 \\
\hline & $7500 \mathrm{C}$ & $1 \mathrm{st}$ to $3 \mathrm{rd}$ & B. taurus & -20.9 & 6.0 & 3.26 & 4.66 \\
\hline & $4179 \mathrm{C}$ & $1 \mathrm{st}$ to $3 \mathrm{rd}$ & B. taurus & -21.8 & 5.8 & 3.20 & 1.73 \\
\hline & $3602 \mathrm{C}$ & 12 th & B. taurus & -20.2 & 5.3 & 3.19 & 8.74 \\
\hline & $1227 \mathrm{C}$ & 14 th & B. taurus & -21.7 & 4.9 & 3.20 & 7.34 \\
\hline & $1184 \mathrm{C}$ & 14 th & B. taurus & -20.8 & 4.9 & 3.19 & 7.32 \\
\hline & $1177 \mathrm{C}$ & 14 th & B. taurus & -21.3 & 8.3 & 3.20 & 6.42 \\
\hline & $1164 \mathrm{~S}$ & 14 th & B. taurus & -20.9 & 11.1 & 3.23 & 4.12 \\
\hline & $8584 \mathrm{~S}$ & $1 \mathrm{st}$ to $3 \mathrm{rd}$ & C. hircus & -19.9 & 4.7 & 3.21 & 2.49 \\
\hline & $8541 \mathrm{~S}$ & $1 \mathrm{st}$ to $3 \mathrm{rd}$ & C. hircus & -20.0 & 4.0 & 3.20 & 9.26 \\
\hline & $8521 \mathrm{~S} 2$ & $1 \mathrm{st}$ to $3 \mathrm{rd}$ & C. hircus & -20.6 & 10.6 & 3.24 & 4.71 \\
\hline & $4311 \mathrm{~S}$ & $1 \mathrm{st}$ to $3 \mathrm{rd}$ & O. aries & -21.3 & 4.5 & 3.29 & 3.13 \\
\hline & $8504 \mathrm{~S}$ & $1 \mathrm{st}$ to $3 \mathrm{rd}$ & O. aries & -20.8 & 5.1 & 3.20 & 4.35 \\
\hline & $8507 \mathrm{~S}$ & $1 \mathrm{st}$ to $3 \mathrm{rd}$ & O. aries & -20.5 & 9.9 & 3.19 & 7.99 \\
\hline & $8513 \mathrm{~S}$ & $1 \mathrm{st}$ to $3 \mathrm{rd}$ & O. aries & -21.6 & 8.3 & 3.23 & 3.57 \\
\hline & $1173 \mathrm{~S}$ & 14 th & O. aries & -20.0 & 5.0 & 3.20 & 4.10 \\
\hline & $8211 \mathrm{~B}$ & $1 \mathrm{st}$ to $3 \mathrm{rd}$ & G. gallus & -19.1 & 10.6 & 3.31 & 5.61 \\
\hline & $8504 \mathrm{~B} 2$ & 1 st to $3 \mathrm{rd}$ & G. gallus & -19.8 & 9.6 & 3.23 & 3.34 \\
\hline & $8504 \mathrm{~B}$ & 1 st to $3 \mathrm{rd}$ & G. gallus & -18.5 & 10.7 & 3.32 & 14.27 \\
\hline & $8507 \mathrm{~B}$ & 1 st to $3 \mathrm{rd}$ & G. gallus & -18.4 & 8.0 & 3.23 & 4.61 \\
\hline & $8503 \mathrm{~B}$ & 1 st to 3 rd & G. gallus & -19.3 & 8.0 & 3.25 & 2.65 \\
\hline & $8541 \mathrm{P}$ & 1 st to 3 rd & Sus domesticus & -18.9 & 6.3 & 3.20 & 2.25 \\
\hline & $8581 \mathrm{P}$ & 1 st to $3 \mathrm{rd}$ & Sus domesticus & -20.4 & 7.2 & 3.18 & 3.75 \\
\hline & $8659 \mathrm{P}$ & 1 st to 3 rd & Sus domesticus & -21.0 & 6.5 & 3.26 & 1.44 \\
\hline & $1269 \mathrm{P}$ & 12 th & Sus domesticus & -20.2 & 7.1 & 3.25 & 3.86 \\
\hline & $1374 \mathrm{P}$ & 12 th & Sus domesticus & -19.1 & 4.9 & 3.43 & 4.14 \\
\hline & $1177 \mathrm{P}$ & 14 th & Sus domesticus & -20.3 & 7.7 & 3.19 & 6.13 \\
\hline & $8510 \mathrm{M}$ & 1 st to 3 rd & C. familiaris & -15.6 & 14.1 & 3.17 & 0.49 \\
\hline & $3833 \mathrm{D}$ & 1 st to 3 rd & C. familiaris & -18.4 & 9.4 & 3.22 & 0.85 \\
\hline & $1254 \mathrm{~B}$ & 12 th & F. catus & -18.5 & 8.9 & 3.17 & 7.5 \\
\hline & $1173 \mathrm{BB}$ & 14 th & F. catus & -18.9 & 6.9 & 3.25 & 9.4 \\
\hline & $8299 \mathrm{H}$ & $1 \mathrm{st}$ to $3 \mathrm{rd}$ & Equus sp. & -18.3 & 6.0 & 3.23 & 1.26 \\
\hline & 1173B & 14 th & O. cuniculus & -21.6 & 5.2 & 3.23 & 2.02 \\
\hline & $8521 \mathrm{~B}$ & $1 \mathrm{st}$ to $3 \mathrm{rd}$ & Corvus corax & -19.4 & 8.6 & 3.19 & 8.75 \\
\hline & $9106 \mathrm{~F}$ & 1 st to $3 \mathrm{rd}$ & M. merluccius & -12.0 & 14.4 & 3.16 & 4.42 \\
\hline & $2076 \mathrm{~F}$ & 12 th & G. galeus & -11.9 & 11.9 & 3.32 & 1.33 \\
\hline
\end{tabular}

still eating animal products. When the population is divided by sex, males are enriched in ${ }^{15} \mathrm{~N}$ compared to the females (Fig. 4). The difference is significant for $\delta^{15} \mathrm{~N}$ but not for $\delta^{13} \mathrm{C}$ (Mann-Whitney $U$ test, $p=0.02$ and $p=0.89$, respectively). In contrast, Muslim individuals from the Lisbon suburb (Calçadinha do Tijolo, CDT), do not show a sex difference in diet. Males and females from CDT have similar values of both $\delta^{13} \mathrm{C}$ and $\delta^{15} \mathrm{~N}$ and plot with the females from the SJC.
A second clear trend is shown by adult and nonadult individuals that display a significant difference in both their $\delta^{13} \mathrm{C}$ and $\delta^{15} \mathrm{~N}$ values (Mann-Whitney $U$ test, $p=0.00$ and $p=0.04$, respectively). The nonadults show a typical breastfeeding signal (Millard 2000; Jay et al. 2008) with individuals of less than 3 years of age enriched in ${ }^{13} \mathrm{C}$ and ${ }^{15} \mathrm{~N}$ (Fig. 4). The individuals older than 3 years seem to have a similar diet to the females. 


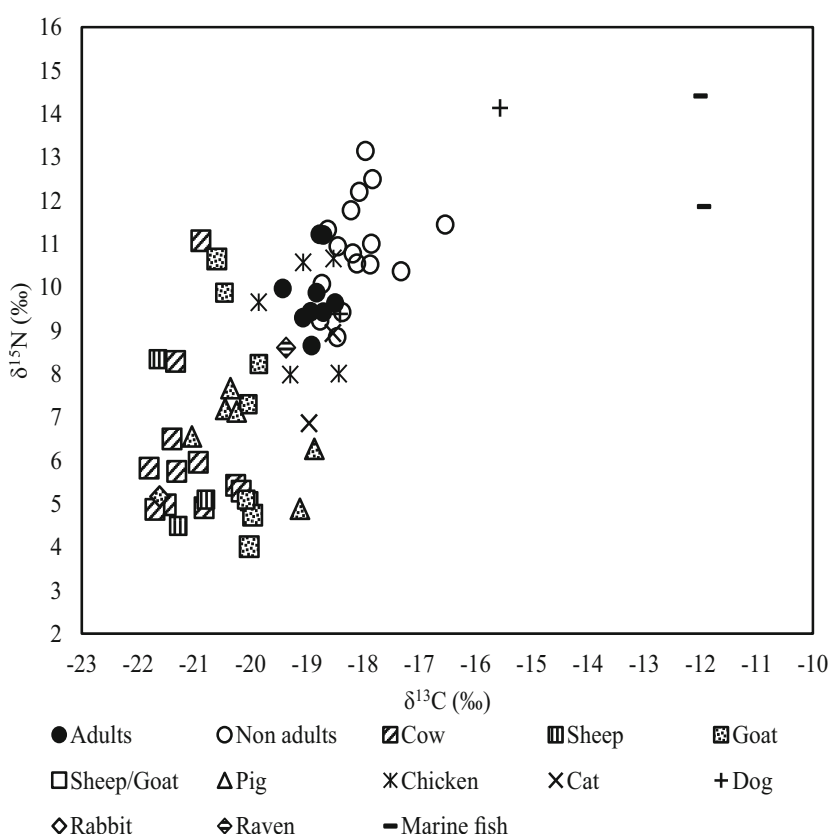

Fig. 3 Plot of $\delta^{13} \mathrm{C}$ and $\delta^{15} \mathrm{~N}$ values for the Muslim individuals from São Jorge Castle (tenth to eleventh centuries) and animals from Praça da Figueira (tenth to eleventh centuries)

\section{Discussion}

\section{Paleopathological assessment}

The São Jorge Castle collection presents low frequencies of stress markers. As observed in other collections, the frequency

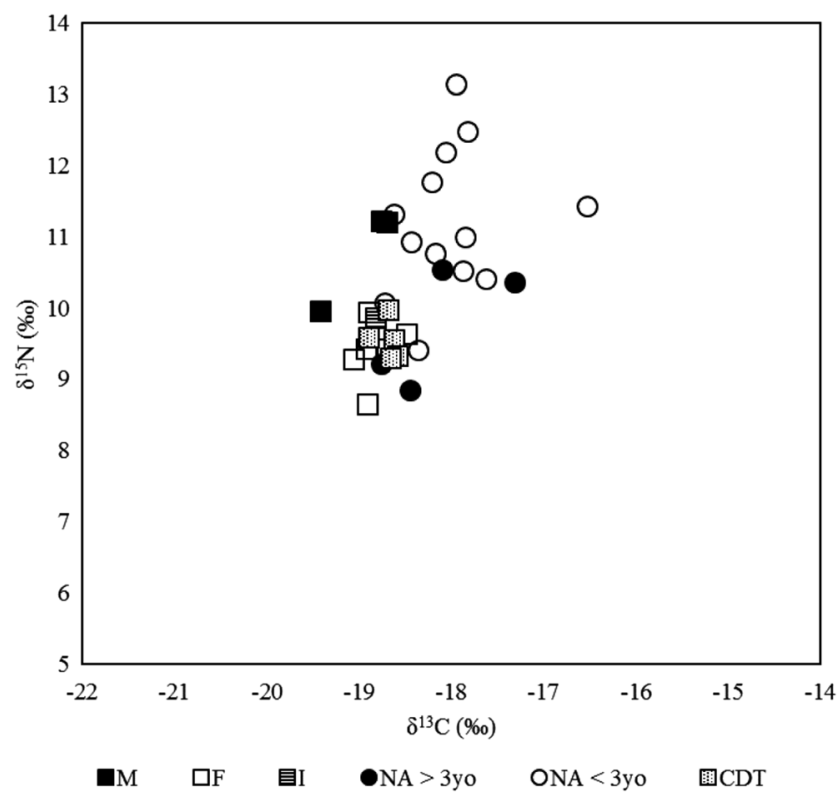

Fig. 4 Plot of $\delta^{13} \mathrm{C}$ and $\delta^{15} \mathrm{~N}$ values of the SJC individuals divided by sex and age groups: males $(\mathrm{M})$, females $(\mathrm{F})$, indeterminate sex (I), non-adults (NA). A comparative sample of Muslim individuals from urban Lisbon (Calçadinha do Tijolo) is included of LEH in the SJC collection is higher in the adults and the $\mathrm{CO}$ frequency is higher in the non-adult sample (Garcia 2007; Herrscher 2001; Robles et al. 1996). LEH is interpreted in bioarchaeology as an indicator of temporary growth disruption associated with a state of illness, undernutrition or both (Goodman 1991; King et al. 2005; Ritzman et al. 2008). Although the frequency of LEH is higher in the adult sample, it reflects the first 6 years of development of an individual. Thus, any event that could explain the formation of LEH had to occur in this timeframe. The non-adults with LEH were older than the ones without, but the small size of the samples demands that the results of the LEH and also of the other stress markers be interpreted with caution.

For instance, as previously mentioned, the frequency of $\mathrm{CO}$ is higher in the non-adult sample in comparison with the adult sample. There are many possible causes associated with $\mathrm{CO}$. The traditional explanation linked the occurrence of $\mathrm{CO}$ with iron deficiency anaemia (Stuart-Macadam 1985) derived either from a deficient intake of iron, a difficulty in its absorption or significant loss. Other explanations are based in the hereditary transmission of haemolytic diseases as sickle cell anaemia or thalassaemia. Although recent discussion had questioned the validity of iron deficiency explanations (Walker 2009), many authors have advocated the importance of not excluding them (Blau 2001; Facchini et al. 2004; Mcllvaine 2015; Oxenham and Cavill 2010; Walker 1986). The funerary context of this sample indicates that these individuals were privileged in Islamic society since they were buried inside the walls of the Lisbon castle. The results of the stable isotope analysis indicated that two individuals with $\mathrm{CO}$ showed a breast-feeding pattern (enrichment in ${ }^{15} \mathrm{~N}$ ) and women and older children exhibited a diet that incorporated lower trophic level protein than males.

The lack of evidence of any infectious disease (including non-specific types), and the low frequencies of stress markers are in keeping with the high status nature of the population. Poor nutrition which may be expected in low status populations is often linked to elevated levels of infectious disease and stress (Larsen 2002). Nevertheless, this collection is characterised by being greatly represented by young nonadults that, although simulate a 'disease-free' population, died before adulthood. The problem of a selective mortality (Wood et al. 1992) should be considered, at least as a theoretical concern. However, studies have been consistent in demonstrating that LEH are more frequent in populations with a lower socio-economic status (Geber 2014; Goodman 1993; Goodman and Roe 1991). In populations with high fertility and high mortality, it is expected to find that around $40 \%$ of the archaeological cemetery are non-adults, but in the Lisbon sample, $60 \%$ of the individuals are under 18 years of age. This pattern emerges when there is an excess of mortality triggered by starvation or other acute health crisis (Geber 2016). However, interpretation of this 
biased mortality profile is hampered by the small number of individuals in this population.

Only one adult individual with erupted permanent teeth had caries. However, other historical populations present much higher frequencies such as Later Medieval Christians from Portugal and Muslims from Spain. For instance, in São Martinho, Leiria, the prevalence of carious lesions in individuals with permanent erupted teeth was 56\%. Adults from São Martinho had a prevalence of caries of $84 \%$ (Garcia 2007). The same is observed comparing the values with the Islamic collection of Xarea, where the prevalence of caries in adults is 73\% (Robledo and Trancho 2003). The relationship between caries and diet has long been investigated and there are many studies that agree that there is a relationship between the ingestion of fermentable carbohydrates and an increase in the metabolic activity of cariogenic bacteria (Powell 1985; Moynihan and Petersen 2004). On the other hand, proteins and dietary fats seem to have a protective effect against caries (Mundorff-Shrestha et al. 1994) due to their basic nature (opposed to the acidic nature of carbohydrates) that slows the bacterial activity (Powell 1995). The low prevalence of caries in the population from the Castle may be the result of consumption of moderate amounts of carbohydrates alongside regular consumption of animal proteins and dietary fats which complements the results of the stable isotope analysis which indicates a reliance on animal products in the diet.

\section{Dietary patterns: stable isotope analysis}

Despite the uncertainty related to the long chronology of the faunal remains, feeding practices for the main domestic species seem to be constant in Lisbon throughout time. The majority of the domestic species show an herbivorous diet based on $\mathrm{C}_{3}$ plants. Notably, a few individuals (two cows, two sheep and one goat) have enriched $\delta^{15} \mathrm{~N}$ values. This wide range in $\delta^{15} \mathrm{~N}$ values for herbivores can occur for a number of reasons. Among these are environmental factors such as temperature, aridity and coastal proximity that vary the isotopic composition of plants (Amundson et al. 2003; Hartman 2011). Specific human land use practices such as manuring can shift the baseline values (Fraser et al. 2011), and animals that are reared near urban centres are more likely to show enriched $\delta^{15} \mathrm{~N}$ values (Hedges et al. 2005; Reitz et al. 2016). Metabolic and physiological pathways between different species could also affect $\delta^{15} \mathrm{~N}$ values; however, this is not the case in Lisbon, since a wide range of values is exhibited among individuals of the same species (Itahashi et al. 2014). The variation in herbivore values can also indicate a wider provisioning area. From historical sources, it is known that animals consumed in urban areas were not always reared near the settlements (Catarino 1998, p. 39). Toponyms in the surrounding of Lisbon, with particular mention of the areas upstream of the river Tagus for the Muslim and Christian period, suggest the existence of pastures (Catarino 1998, p. 34; Gomes Barbosa 1994, p. 20). Thus, these differences in herbivore diet suggest distinct management strategies and/or provenance for these individuals.

Nitrogen isotope signatures for chickens are very close to the human individuals from SJC which indicates that they were fed on domestic food waste. Both food scraps and insects, typically included in the chicken diet, have enriched nitrogen isotope values (Reitz et al. 2016) and a similar pattern of human and chicken values have been found at a late medieval Muslim site (Alexander et al. 2015). The two pigs of Islamic chronology plot similarly to the herbivores and pigs from other periods, therefore indicating that they may possibly be wild; however, we cannot be certain since pigs have shown very variable isotope values in previously analysed medieval assemblages (Halley and Rosvold 2014). The single dog exhibits surprising enrichment in both ${ }^{13} \mathrm{C}$ and ${ }^{15} \mathrm{~N}$ in comparison to both animals and humans. The isotopic values suggest a diet based on marine resources, which is unique among the individuals sampled here. However, this is a juvenile (unfused femur) and therefore may retain a nursing signal; furthermore, the dog derives from Roman contexts and so may not be indicative of Medieval subsistence or husbandry in the city.

Turning to the human diet, in terms of animal protein, given the aforementioned wide range in nitrogen isotope values for animals, it is difficult to pin down specific species that were consumed. It is likely that herbivores played a significant part in the diet of these individuals, with omnivores such as chickens supplementing the diet of some, particularly those with higher nitrogen isotope values. Perhaps the most notable feature of the human results is that despite the coastal location of Lisbon, marine resources do not appear to play a major role in the human diet, with humans possessing carbon and nitrogen isotope values indicative of a terrestrial, $\mathrm{C}_{3}$-based diet. This is surprising given the location of Lisbon and its intrinsic relationship with both the sea and the river Tagus. However, limited consumption of low trophic level fish that typically live near the coast would not be detected by isotopic analysis. As well, dietary models indicate that a terrestrial-based diet could include up to $20 \%$ marine protein without raising bone collagen $\delta^{13} \mathrm{C}$ values, therefore underrepresenting marine food unless consumed in substantial amounts (Hedges 2004; Milner et al. 2004). Freshwater fish, although a plausible and abundant resource in the Tagus River, was probably not widely consumed. In this regard, cultural and religious preferences should also be considered. The Quran does not prohibit the consumption of fish; however, some sections of Islam did consider it unlawful, mainly in the Eastern Shia tradition (Pellat et al. 2012). Arab authors, following their Greek predecessors, had different opinions on the benefit of fish; however, it was commonly believed that fish were less nutritious than meat and generally not as good for human consumption (García-Sánchez 1986, p. 259). 
Fish recipes are also very scarce in medieval Andalusian cookbooks, usually accounting for $4-10 \%$ of the presented recipes (García-Sánchez 1986, pp. 264-265). The only medieval Portuguese cookbook available unfortunately dates to the late medieval Christian period (Manuppella 1987). A lack of zooarchaeological data also hinders the assessment of the consumption of marine resources in Islamic Lisbon. Sieving is not routinely carried out due to the time constraints that recovery processes imposed on rescue and commercial archaeology in the city.

There is no indication of $\mathrm{C}_{4}$ plants in the diet of the humans or animals from Lisbon. This is despite historical records indicating that they were available. $\mathrm{C}_{4}$ plant consumption has been found in isotopic studies of medieval Muslim populations from Valencia (Alexander et al. 2015; Salazar-García et al. 2014) and in late antique and medieval populations in Galicia (López-Costas 2012; López-Costas and Müldner 2016). Crops such as millet and sorghum may have been considered to be low status crops (Alexander et al. 2015; GarcíaSánchez 1996, p. 223), and the lack of evidence for them in the diet, especially among the SJC individuals, may reflect the privileged status of this population.

\section{Sex-related trends in diet}

When considering the diet of this population in relation to sex, women and men display a different diet (Fig. 4), with males generally possessing higher $\delta^{15} \mathrm{~N}$ than females. This could indicate that males derived a greater proportion of their dietary protein from animal rather than plant sources in comparison to females or that they consumed higher trophic level protein from chickens or potentially freshwater fish, which would also serve to enrich $\delta^{15} \mathrm{~N}$ values (Hedges and Reynard 2007). This sex difference in food consumption could be an expression of family organisation and use of domestic space where men, women and children may not have necessarily eaten together. This connection between family and domestic architecture has been studied in medieval Morocco. The centralised structure of the houses in Maghreb with equal cells surrounding a central space is said to reflect the family structure of its inhabitants: wives and children are relatively equal to each other but subordinate to the male head of the household (Fentress 2000). Historical sources from as early as the eleventh century describe specific spaces for women within a household or palace in Al-Andalus (Díez Jorge 2002, p. 159). In the household, the man was required to provide a separate room for his wife and a separate house if he married a second wife (Pérez Ordóñez 2009, p. 5). A series of such norms and regulations about the use of domestic space are reported (Marín 2000, p. 237), but these regulations were more feasible in large, high status household with many rooms. In high status contexts, the Arab-Islamic table was dominated by men; women could watch the banquet from a shielded area or eat separately in their part of the house (Lewicka 2011, p. 401; Visser 2012, p. 279).

When the high status population from the castle is compared with a contemporaneous Muslim urban population from $\mathrm{CDT}$, female individuals from the castle have a very similar diet to these lower status individuals that include both females and males (Fig. 4), who, in this context, show no sex-related differences in diet. In the case of the nuclear, one-room houses common for those of lower status across Islamic settlements, such as those excavated in Praça da Figueira (Díez Jorge 2002, p. 161), it is probable that men and women were more likely to share space and food. In a similar vein, medium and lowerstatus women were less restricted in their daily activity, being free to wander in public spaces and use the public baths, unlike women of high status (Coope 2013; Lachiri 1993). This may be why there is no sex difference detected among low status individuals.

Therefore, it appears that high status males are more distinctive in their eating habits compared to the rest of the urban population of the time. This difference for the high status male individuals could be linked to their activities taking place outside the home and them potentially having access to a wider range of foodstuffs, including sources enriched in ${ }^{15} \mathrm{~N}$ as mentioned above. In terms of a typical high status male diet, one could infer that the entirety of etiquette manuals and cookery books were actually intended for higher-status male individuals and are therefore a reliable source of information, i.e. a diet rich in animal products. The fact that the low status population and the high status females have similar diets might be a reflection of the consumption of comparatively less meat by both these social groups.

Similar patterns in isotopic data in relation to sex, with males consuming higher trophic level proteins, have been recorded elsewhere in Muslim Spain, at Tauste, for example (Guede et al. 2017a, b), where males were hypothesised to consume more freshwater fish. However, the evidence from this study and other published populations from Spain indicates that a sex difference in diet is not a consistent trend among isotopic datasets for Muslim populations (Alexander et al. 2015; Fuller et al. 2010; Salazar-García et al. 2014, 2016). The small sample sizes from Lisbon hamper any definite conclusions regarding diet and sex, although the role of status in a possible male/female differentiation in food consumption is hypothesised.

\section{Age-related trends in diet}

The weaned non-adults of this population share a similar diet to the females. There are few explicit references in historic literature for culinary products shared by women and children. Women and children were considered of different physiological nature (children were hot and humid, while women were 
colder and drier); therefore, this similar food consumption is not associated with the humoral theories (Oliveira 2007, p. 31). However, childcare is traditionally entrusted to women and it is likely that physical proximity would have prompted the consumption of similar meals. To the best of our knowledge, it is the first time a similar trend is shown by isotopic data in an Islamic population and further exploration of non-adult diet is needed to assess the prevalence of this practice.

Breastfeeding, although sometimes performed by wetnurses among high status families, was considered by Christian and Muslim medieval societies of vital importance to child development and health (Giladi 1998, p. 108; Shahar 1990, p. 57; Winer 2008). Our results show that the majority of the non-adults under the age of three were still breastfed in accordance with medical and historical sources from both the Muslim and Christian world, which suggested breastfeeding to at least until 2 years of age (Baumgarten 2004; Fildes 1986). When compared to other archaeological medieval populations, the individuals from SJC appear to follow a similar pattern of enriched nitrogen isotope values compared to the females' mean value of their respective populations (Fig. 5). This is the expected signature for breastfeeding and weaning and can be observed across all sites. The nitrogen isotope ratios start to decrease at SJC around 2 years of age, as would be expected from historical sources, while at other sites such as Grenoble, Fishergate, Raunds and Tauste, the weaning period seems to occur slightly later. However, a lack of individuals between the age of 2 and 6 years old at SJC could mask a similar pattern and prevent a more precise estimate of the weaning age of this Muslim population. Incremental dentine layers analysis may have served to pinpoint weaning times with greater precision (King et al. 2018); however, sampling restrictions did not permit destructive analysis of dentition. It should also be borne in mind that due to the 'osteological paradox' (Beaumont et al. 2015; Wood et al. 1992), the nonadults here are non-survivors that may not reflect the dietary practice of the 'healthy' population (Beaumont et al. 2015).

\section{Diet and status}

Status played an important role in food access, both in terms of quantity, quality and variety of the available resources. High status people not only had easier access to a greater quantity of food but also to a wider selection of products. Previous studies on medieval population in Sweden (Bäckström et al. 2017; Linderholm et al. 2008), UK (Müldner and Richards 2007, Müldner et al. 2009), Italy (Reitsema and Vercellotti 2012) and France (Colleter et al. 2017) have explored the influence of status on diet, examining the correlation between isotopic values and graves goods or burial type. In these previous examples, more high status individuals consumed marine protein and/or higher trophic level terrestrial protein. Although the small sample size constitutes a limitation in the SJC assemblage, the sex-related difference in diet that was found in this population may be an expression of its social status, further supported by the lack of any sexrelated difference in diet in the urban population of Calçadinha do Tijolo.

Contemporaneous (tenth to thirteenth centuries) medieval high status individuals have been recently analysed from the Royal Houses of Castile and Aragon (Jiménez-Brobeil et al. 2016; Martínez-Jarreta et al. 2017). The Royal members showed higher $\delta^{15} \mathrm{~N}$ compared to other medieval Spanish populations suggesting the inclusion of higher trophic level protein such as pig and freshwater fish. Although the difference between female and male $\delta^{15} \mathrm{~N}$ values is not significant, males have higher $\delta^{15} \mathrm{~N}$ mean $(12.8 \% \circ \pm 1.3)$ than females $(11.3 \% \circ \pm 1.7)$. While the Spanish royal members, both females and males, showed higher $\delta^{15} \mathrm{~N}$ values compared to contemporaneous populations; in
Fig. 5 Breastfeeding and weaning pattern of non-adult individuals from SJC, Lisbon and Monte da Cegonha compared to other Muslim and Christian populations from Spain, France and UK. The comparative sites are Monte da Cegonha, Portugal (Saragoça et al. 2016), Tauste, Spain (Guede et al. 2017a, b), Can Fonoll, Ibiza, Spain (Pickard et al. 2017), El Raval, Spain (SalazarGarcía et al. 2014), Grenoble, France (Herrscher 2003), Wharram Percy, UK (Richards et al. 2002), York, UK (Burt 2013), and Raunds, UK (Haydock et al. 2013)

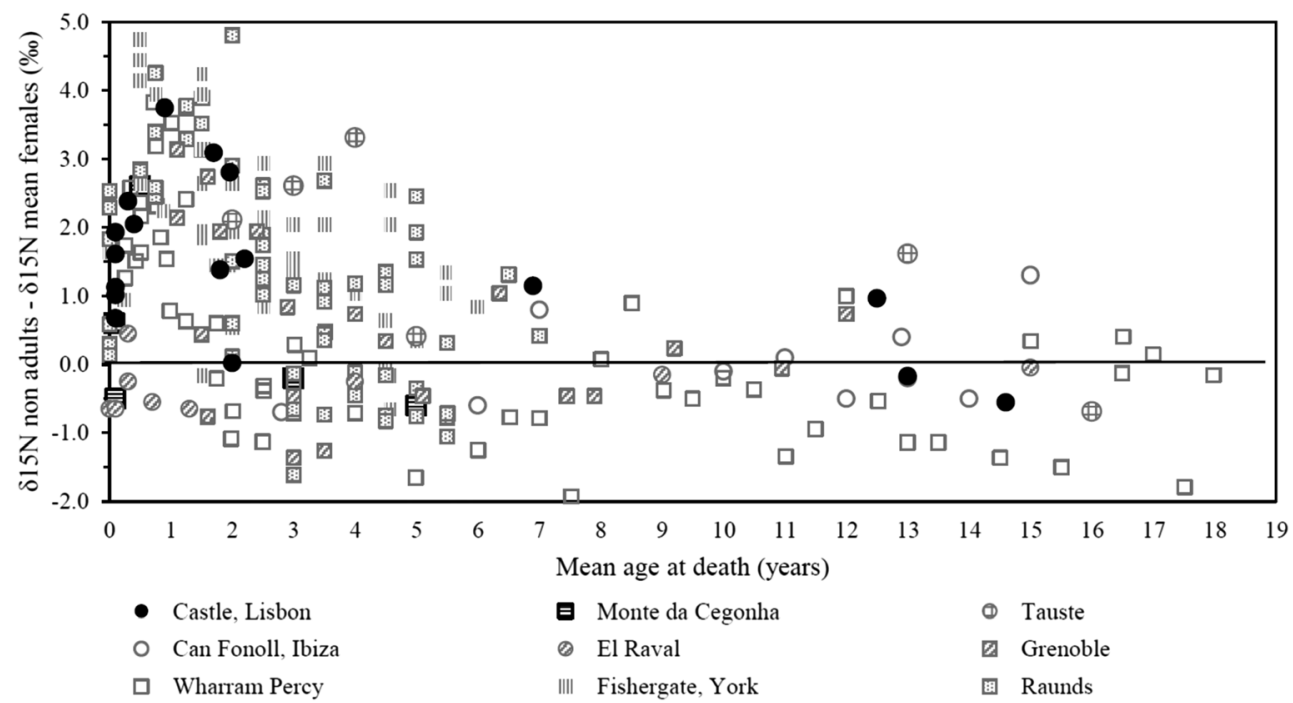


Lisbon, this status-related difference can be seen in males only, similarly to what was found at Whithorn Cathedral Piory (Müldner et al. 2009), Fishergate, York (Müldner and Richards 2007) and Brittany (Colleter et al. 2017).

\section{Wider comparison with the Iberian dataset}

The two Lisbon populations (SJC and Calçadinha do Tijolo) were compared to contemporaneous populations from the Iberian Peninsula (Fig. 6). The comparison indicates that there is an extremely similar diet shared by the ninth to eleventh century Lisbon and the Portuguese Late Antique individuals from Monte das Cegonhas, suggesting the continuation of dietary practice between the Late Antique and the Islamic period. More widely, similar mean isotopic values are exhibited by contemporaneous Muslim populations from Tossal de les Basses (Alicante), the Balearic Islands, and a Late Antique population from Madrid (Cau Ontiveros et al. 2016; Lubritto et al. 2017; Nehlich et al. 2012; Pickard et al. 2017; SalazarGarcía et al. 2016). The stark difference between Portuguese sites and data from Galicia is notable (López-Costas and Müldner 2016), with the latter exhibiting higher $\delta^{13} \mathrm{C}$ values despite the fact that both geographic areas overlook the Atlantic coast and may be assumed to have similar diets, or at least more similar than populations from the Mediterranean coast of Iberia. Isotopic data have indicated that $\mathrm{C}_{4}$ crops and marine resources were heavily relied upon at least from the Roman period which would both serve to increase $\delta^{13} \mathrm{C}$ values; however, this cannot be seen along the Portuguese coast during the early medieval period (López-Costas and Müldner 2016). It should be borne in mind that some of the differences here will be not only be related to cultural preferences but will also be linked to the environment and climate in each region and any differences may reflect baseline rather than dietary shifts. This is particularly relevant for Tauste, where the consumption of freshwater resources and/or the presence of individuals from more arid climates might have affected the nitrogen isotope values.

The ${ }^{15} \mathrm{~N}$ enrichment exhibited by two males (CAS1PN, CAS1PC) may alternatively be explained by a possible different geographical origin. Individuals from arid climates tend to possess higher $\delta^{15} \mathrm{~N}$ values (e.g. Dupras and Schwarcz 2001; Schwarcz et al. 1999). During this period of Islamic rule in Iberia, it is highly likely that people were moving from North Africa to the Iberian Peninsula, facilitated by their shared political (and cultural) systems. However, available historical sources lack specific information on this issue. Further analysis of isotopes such as strontium, oxygen or possibly ancient DNA would be needed to explore the theme of mobility at a deeper level.

\section{Conclusion}

In the São Jorge Castle, the frequencies of stress indicators were found to be low and followed a common pattern of age
Fig. 6 Comparison of Lisbon populations (SJC and Calçadinha do Tijolo) with other medieval Iberian populations. The values are presented as a mean, error bars represent $\pm 1 \sigma$

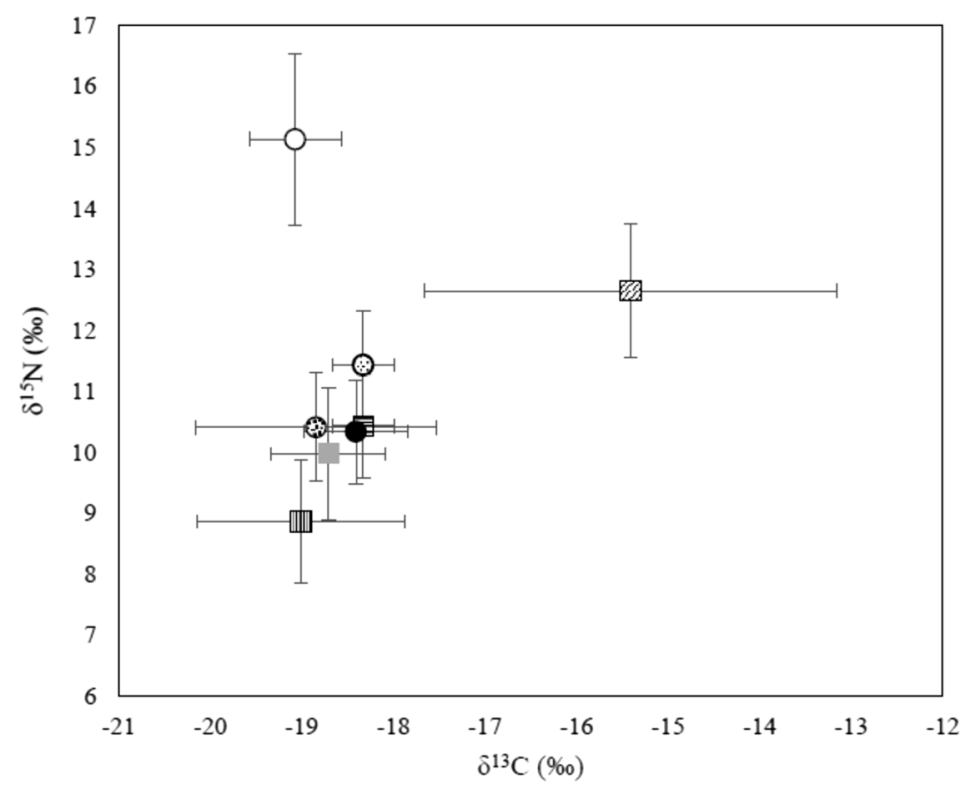

Galicia 5th-15th $(\mathrm{n}=35)$

m Basque Country and Burgos 6th-14th ( $\mathrm{n}=163)$

Madrid 6th-8th $(\mathrm{n}=38)$

目Monte das Cegonhas 7th-9th $(\mathrm{n}=23)$

OTauste 8 th-10th $(\mathrm{n}=31)$

$\odot$ Balearic Islands 10th-13th $(\mathrm{n}=133)$

-Tossal de les Basses 8th-9th ( $n=14)$

- Lisbon 9th-11th (n=32) 
distribution in respect to LEH and CO. LEH is more common in older individuals, and $\mathrm{CO}$ and $\mathrm{HL}$ in young individuals. The absence of evidence of infectious diseases (including non-specific) and the low frequency of stress markers may reflect the high status nature of the population. However, the small samples size demands caution.

The isotopic results indicate a terrestrial, $\mathrm{C}_{3}$-based subsistence economy. The isotopic signature of the animals, although representing a long chronology, does not show significant changes over time, suggesting a certain degree of continuity in economy and animal husbandry practices between the Roman and Medieval periods in Lisbon. Again, however, the sample size is small and further analyses could explore this observation more fully. All domestic animals were fed or grazed on $\mathrm{C}_{3}$ plants, although some variation due to climate, environmental and physiological factors might have affected the nitrogen isotope values of certain individuals. Results for humans suggested a sex-based difference in diet, with females and non-adults relying on lower trophic level proteins compared to males. In addition, females and non-adults showed a very similar diet, implying that the close proximity of these two groups may have prompted communal consumption practices. These patterns, absent in other Islamic urban populations published from Iberia thus far, may reflect the strict division of sex and age groups in the Islamic household predominantly followed by the higher classes. There is no difference, however, between the privileged females analysed from the castle and males and females from the general population buried outside the castle at Calçadinha do Tijolo. Although the sample size is small, a tentative shift towards high status males exhibiting enrichment in ${ }^{15} \mathrm{~N}$ is proposed, following a trend seen among other sites in Medieval Europe. The combined bioarchaeological approach used here offers the first detailed insight into the lifeways of high status Islamic populations from Iberia. A major investment in similar studies of other Islamic collections will provide valuable information to allow a better understanding of life and death across Islamic society in Al-Andalus.

Acknowledgments The authors thank Dr. Alexandra Gaspar and Dr. Ana Gomes and Dr. António Marques who granted permission to study the collections. The radiographs were done in Hospital Escolar Veterinário, Faculdade de Medicina Veterinária, with the assistance of Dr. António Ferreira and Dr. Óscar Gamboa. Thanks are also due to Luke Spindler for his help with ZooMS analysis; to Matthew Von Tersch for assistance in mass spectrometry; and to Dr. David Orton who identified the animal remains. Further acknowledgements go to the members of the Faith in Food and Food in Faith White Rose network and especially to Dr. Iona McCleery for her guidance throughout this work. Finally, we would like to thank the two anonymous reviewers for their comments on the manuscript.

Funding information Grant sponsor: AHRC PhD Network Studentship awarded (White Rose College of the Arts and Humanities at the University of York); Santander International Connection award 2014; Barakat Trust Award 2015; Archaeology of Portugal Fellowship 2016; BioArCh, Department of Archaeology, University of York.
Open Access This article is distributed under the terms of the Creative Commons Attribution 4.0 International License (http:// creativecommons.org/licenses/by/4.0/), which permits unrestricted use, distribution, and reproduction in any medium, provided you give appropriate credit to the original author(s) and the source, provide a link to the Creative Commons license, and indicate if changes were made.

\section{References}

Adamson MW (2004) Food in medieval times. Greenwood Press, Westport

Alexander MM, Gerrard CM, Gutiérrez A, Millard AR (2015) Diet, society, and economy in late medieval Spain: stable isotope evidence from Muslims and Christians from Gandía, Valencia. Am J Phys Anthropol 156:263-273

Amundson R, Austin AT, Schuur EA, Yoo K, Matzek V, Kendall C, Uebersax A, Brenner D, Baisden WT (2003) Global patterns of the isotopic composition of soil and plant nitrogen. Glob Biogeochem Cycles 17(1):1031

Antunes MT (1996) Alimentação de origem animal em regime islâmicoAlcaria Longa e Casa II da Alcáçova de Mértola. Arqueologia Medieval 4:267-276

Bäckström Y, Mispelaere J, Ingvarsson A, Fjellström M, Britton K (2017) Integrating isotopes and documentary evidence: dietary patterns in a late medieval and early modern mining community, Sweden. Archaeol Anthropol Sci:1-20

Baumgarten E (2004) Mothers and children: Jewish family life in medieval Europe. Princeton University Press, Princeton

Beaumont J, Montgomery J, Buckberry J, Jay M (2015) Infant mortality and isotopic complexity: new approaches to stress, maternal health, and weaning. Am J Phys Anthropol 157:441-457

Blau S (2001) Limited yet informative: pathological alterations observed on human skeletal remains from third and second millennia $\mathrm{BC}$ collective burials in the United Arab Emirates. Int J Osteoarchaeol 11(3):173-205

Bocherens H, Drucker D (2003) Trophic level isotopic enrichment of carbon and nitrogen in bone collagen: case studies from recent and ancient terrestrial ecosystems. Int J Osteoarchaeol 13(1-2):46-53

Brooks S, Suchey JM (1990) Skeletal age determination based on the os pubis: a comparison of the Acsádi-Nemeskéri and Suchey-Brooks methods. Hum Evol 5:227-238

Brown TA, Nelson DE, Vogel JS, Southon JR (1988) Improved collagen extraction by modified Longin method. Radiocarbon 30:171-177

Bruzek J (2002) A method for visual determination of sex, using the human hip bone. Am J Phys Anthropol 117:157-168

Bugalhão J (2009) Lisboa Islâmica: uma realidade em construção. Xelb 9: 379-393

Bugalhão J, Queiroz PF (2006) Testemunhos do consumo de frutos no período islâmico em Lisboa. In: Gómez Martínez S (ed) Al-Ândalus Espaço de mudança. Campo Arqueológico de Mértola, Mértola, pp 195-212

Bugalhão J, Gomes S, Sousa MJ, Folgado D (2008) Produção e consumo de cerâmica islâmica em Lisboa: conclusões de um projecto de investigação. Arqueologia Medieval 10:113-134

Burt NM (2013) Stable isotope ratio analysis of breastfeeding and weaning practices of children from medieval Fishergate House York, UK. Am J Phys Anthropol 152:407-416. https://doi.org/10. 1002/ajpa.22370

Cardoso JL (1993) Contribuição para o conhecimento da alimentação em contexto islâmico: estudo dos restos mamalógicos e malacológicos das Mesas do Castelinho (Almodôvar). Arqueologia Medieval 2: 103-107 
Cardoso HFV (2000) Dimorfismo sexual na estatura, dimensões e proporções dos ossos longos dos membros: o caso de uma amostra portuguesa dos séculos XIX-XX. Master Dissertation, Coimbra University

Cardoso HFV (2005) Patterns of growth and development of the human skeleton and dentition in relations to environmental quality. $\mathrm{PhD}$ Dissertation, McMaster University

Cardoso HFV (2008) Age estimation of adolescent and young adult male and female skeletons II, epiphyseal union at the upper limb and scapular girdle in a modern Portuguese skeletal sample. Am J Phys Anthropol 137(1):97-105

Cardoso JL, Fernandes ICF (2012) A economia alimentar dos muçulmanos e dos cristãos do Castelo de Palmela: um contributo. Arqueologia Medieval:211-233

Catarino MM (1998) Na margem direita do Baixo Tejo: paisagem rural e recursos alimentares (sécs. XIV e XV). Universidade de Lisboa, Mestrado

Cau Ontiveros MÁ, Van Strydonck M, Boudin M et al (2016) Christians in a Muslim world? Radiocarbon dating of the cemetery overlaying the forum of Pollentia (Mallorca, Balearic Islands). Archaeol Anthropol Sci:1-10

Coelho C (2012) Castelo de Sintra: testemunhos da dieta alimentar nos séculos X-XII. In: Gomez Martinez S (ed) Memória dos sabores do Mediterrâneo. Campo Arqueologico de Mertola/Centro de Estudos Arqueológicos das Universidades de Coimbra e Porto, Mértola, pp 101-112

Colleter R, Clavel B, Pietrzak A, Duchesne S, Schmitt L, Richards MP, Telmon N, Crubézy É, Jaouen K (2017) Social status in late medieval and early modern Brittany: insights from stable isotope analysis. Archaeol Anthropol Sci 9:1-5

Coope J (2013) An etiquette for women: women's experience of Islam in Muslim Spain. EMSt 29:75-83

Costa C, Lopes G (2012) O Paço dos Lobos da Gama: faunas do arrabalde ocidental de Évora islâmica. In: de Deus MMM (ed) Actas do V Encontro de arqueologia do Sudoeste peninsular : Almodôvar, 18 a 20 de novembro de 2010. Município de Almodôvar, Almodôvar, pp 795-808

Davis SJM (2006) Faunal remains from Alcáçova de Santarém, Portugal. Instituto português de Arqueologia, Lisboa

Davis S, Gonçalves M, Gabriel S (2008) Animal remains from a Moslem period (12th/13th century AD) lixeira (garbage dump) in Silves, Algarve, Portugal. Rev Port Arqueol 11:183-258

Detry C, Cardoso JL, Correia VH (2014) What did the Romans and Moslems eat in Conimbriga (Portugal)? The animal bones from the 1990's excavations. In: Detry C, Dias R (eds) Proceedings of the First Zooarchaeology Conference in Portugal. Faculty of Letters, University of Lisbon, Lisbon pp 97-110

Díez Jorge ME (2002) El espacio doméstico: lo femenino y lo masculino en la ciudad palatina de la Alhambra. Cuadernos de la Alhambra 38: $155-181$

Dupras TL, Schwarcz HP (2001) Strangers in a strange land: stable isotope evidence for human migration in the Dakhleh Oasis, Egypt. J Archaeol Sci 28(11):1199-1208

Dutour O (1989) Hommes fossiles du Sahara. Peuplements holocènes du Mali septentrional. Éditions du CNRS, Paris

Facchini F, Rastelli E, Brasili P (2004) Cribra orbitalia e cribra cranii on roman skeletal remains from Ravena area and Rimini (I-IV century AD). Int J Osteoarchaeol 14:126-136

Fentress E (2000) Social relations and Domestic space in the Maghreb. Collection de l'Ecole française de Rome 105:15-26

Fernandes IC, Cardoso JL, Detry C (2015) Cozinhar e comer no castelo medieval de Palmela. In: Gomez Martinez S (ed) Memórias dos sabores do Mediterrâneo. Campo Arqueologico de Mertola/ Centro de estudos Arqueológicos das Universidades de Coimbra e Porto, Mertola, pp 113-127
Fildes VA (1986) Breasts, bottles, and babies: a history of infant feeding. Edinburgh University Press, Edinburgh

Filipe V, Toso A, Inocêncio J (2018) Perspectivas arqueobiológicas sobre a necrópole islâmica de Alfama. In: I Encontro de Arqueologia de Lisboa: Uma Cidade em Escavação. CAL/DPC/DMC/CML, Lisboa

Fraser RA, Bogaard A, Heaton T, Charles M, Jones G, Christensen BT, Halstead P, Merbach I, Poulton PR, Sparkes D, Styring AK (2011) Manuring and stable nitrogen isotope ratios in cereals and pulses: towards a new archaeobotanical approach to the inference of land use and dietary practices. J Archaeol Sci 38(10):2790-2804

Fuller BT, Márquez-Grant N, Richards MP (2010) Investigation of diachronic dietary patterns on the islands of Ibiza and Formentera, Spain: evidence from carbon and nitrogen stable isotope ratio analysis. Am J Phys Anthropol 143:512-522

Gabriel S (2003) Estudos dos restos faunísticos do Silo 1 dos Paços do Concelho de Torre Vedras. Trabalhos do CIPA 48:1-33

Garcia S (2005/2006) Conservação diferencial dos esqueletos humanos da série medieval de S. Martinho (Leiria): implicações para a paleodemografia e para a paleopatologia. Antropol Port 22(23): 273-294

Garcia MSJ (2007) Maleitas do corpo em tempos medievais: indicadores paleodemográficos, de stresse e paleopatológicos numa série osteológica urbana de Leiria. PhD Dissertation. University of Coimbra

Garcia E, Eulalia Subira M, Richards P (2004) Régime et société d'après l'analyse des isotopes stables: l'exemple de la population de «Can Reinés» (Mallorca, Espagne, 600 ap. J.C.). Antropo 7:171-176

García-Sánchez E (1986) La alimentación en la Andalucía islámica. Estudio histórico y bromatológico. In: Bosch Vila J, Hoenerbach W (eds) Andalucía Islámica. Textos y estudios, Soproargra, pp 237-278

García-Sánchez E (1996) La alimentación popular urbana en Al-Andalus. Arqueologia Medieval 4:219-235

Gaspar A, Gomes A (2001) Resultados preliminares das escavações arqueológicas no Castelo de S. Jorge. In: Torres C (ed) Lisboa, encruzilhadas de Muçulmanos, Judeus e Cristãos. Edições Afrontamento, Lisboa pp 95-102

Geber J (2014) Skeletal manifestations of stress in child victims of the Great Irish Famine (1845-1852): prevalence of enamel hypoplasia, Harris lines, and growth retardation. Am J Phys Anthropol 155:149 161

Geber J (2016) Children in a ragged state': seeking a biocultural narrative of a workhouse childhood in Ireland during the Great Famine (1845-1852). Childhood in the Past 9(2):120-138. https://doi.org/ 10.1080/17585716.2016.1205344

Giladi A (1998) Breast-feeding in medieval Islamic thought: a preliminary study of legal and medical writings. J Fam Hist 23:107-123

Gomes A, Gaspar A, Pimenta J et al (2003) Castelo de São Jorgebalanço e perspectivas dos trabalhos arqueológicos. Património Estudos 4:214-223

Gonçalves I (1989) O património do mosteiro de Alcobaça nos séculos XIV e XV. Universidade Nova de Lisboa, Faculdade de Ciências Sociais e Humanas

Gonçalves I (2004) Entre a abundância e a miséria: as práticas alimentares da Idade Média portuguesa. In: Andrade AA, Silva JCV. da (eds). Estudos medievais. Quotidiano medieval: imaginário, representação e práticas. Livros Horizonte, Lisboa, pp 43-65

Goodman AH (1991) Stress, adaptation and enamel developmental defects. In: Ortner DJ, Aufdeheide AC (eds) Human paleopathology. Current synthesis and future options. Smithsonian Institution Press, Washington DC, pp 280-287

Goodman AH (1993) On the interpretation of health from skeletal remains. Curr Anthropol 34(3):281-288

Goodman AH, Roe JC (1991) Dental enamel hypoplasias as indicators of nutritional status. Advances in Dental Anthropology 5:225-240 
Gomes Barbosa P (1994) Lisboa - O Tejo, a Terra e o Mar (e outros estudos). Colibri, Lisboa

Guede I, Ortega LA, Zuluaga MC et al (2015) Stable isotope evidence for palaeodiet dissimilarities associated to sexual dimorphism in the Muslim society of Tauste (Spain). In: 1st International Conference on Metrology for Archaeology. Proceedings. University of Sannio, University of Salerno, Salerno, pp 413-418

Guede I, Ortega LA, Zuluaga MC, Alonso-Olazabal A, Murelaga X, Pina M, Gutierrez FJ, Iacumin P (2017a) Isotope analyses to explore diet and mobility in a medieval Muslim population at Tauste (NE Spain). PLoS One 12:1-27

Guede I, Ortega LA, Zuluaga MC et al (2017b) Isotopic evidence for the reconstruction of diet and mobility during village formation in the Early Middle Ages: Las Gobas (Burgos, northern Spain). Archaeol Anthropol Sci:1-12

Halley DJ, Rosvold J (2014) Stable isotope analysis and variation in medieval domestic pig husbandry practices in northwest Europe: absence of evidence for a purely herbivorous diet. J Archaeol Sci $1(49): 1-5$

Hartman G (2011) Are elevated $\delta 15 \mathrm{~N}$ values in herbivores in hot and arid environments caused by diet or animal physiology? Funct Ecol 25: $122-131$

Haydock H, Clarke L, Craig-Atkins E et al (2013) Weaning at AngloSaxon Raunds: Implications for changing breastfeeding practice in Britain over two millennia. Am J Phys Anthropol 151:604-612. https://doi.org/10.1002/ajpa.22316

Hedges RE (2004) Isotopes and red herrings: comments on Milner et al. and Lidén et al. Antiquity 78(299):34

Hedges RE, Reynard LM (2007) Nitrogen isotopes and the trophic level of humans in archaeology. J Archaeol Sci 34(8):1240-1251

Hedges RE, Thompson J, Hull BD (2005) Stable isotope variation in wool as a means to establish Turkish carpet provenance. Rapid Commun Mass Spectrom 19(22):3187-3191

Herrscher E (2001) Contribuition de l'analyse paléoépidémiologique et paléobiogéochimique à la connaissance de la santé et de l'alimentation à la fin du Moyan Age. Eglise Saint-Laurent de Grenoble (XIIIe-XVe siècle, France). PhD Dissertation. Institute de Paléontologie Humaine

Herrscher E (2003) Alimentation d'une population historique. Analyse des données isotopiques de la nécropole Saint-Laurent de Grenoble (XIIIe-Xe siècle, France). Bull Mém Soc Anthropol Paris 15(3-4) | 2003 2003(3-4) 149-269

Hillson S (2001) Recording dental caries in archaeological human remains. Int J Osteoarchaeol 11(4):249-289

Insoll T (1999) The archaeology of Islam. Blackwell publisher, Oxford

Ïșcan MY, Loth SR, Wright RK (1984) Age estimation from the rib by phase analysis: white males. J Forensic Sci 29:1094-1104

Ïșcan MY, Loth SR, Wright RK (1985) Age estimation from the rib by phase analysis: white females. J Forensic Sci 30:853-863

Itahashi YU, Chikaraishi Y, Ohkouchi N, Yoneda M (2014) Refinement of reconstructed ancient food webs based on the nitrogen isotopic compositions of amino acids from bone collagen: a case study of archaeological herbivores from Tell Ain el-Kerkh, Syria. Geochem J 48:e15-e19

Jay M, Fuller BT, Richards MP, Knusel CJ, King SS (2008) Iron age breastfeeding practices in Britain: isotopic evidence from Wetwang Slack, East Yorkshire. Am J Phys Anthropol 136:327-337

Jiménez-Brobeil SA, Laffranchi Z, Maroto RM et al (2016) How royals feasted in the court of Pedro I of Castile: a contribution of stable isotope study to medieval history. J Archaeol Sci Rep 10:424-430

Jørkov MLS, Heinemeier J, Lynnerup N (2007) Evaluating bone collagen extraction methods for stable isotope analysis in dietary studies. J Archaeol Sci 34(11):1824-1829

King T, Humphrey LT, Hillson S (2005) Linear enamel hypoplasias as indicators of systemic physiological stress: evidence from two known age-at-death and sex populations from postmedieval London. Am J Phys Anthropol 128(3):547-559

King CL, Millard AR, Gröcke DR, Standen VG, Arriaza BT, Halcrow SE (2018) A comparison of using bulk and incremental isotopic analyses to establish weaning practices in the past. STAR 3(1):1-9

van Klinken GJ (1999) Bone collagen quality indicators for palaeodietary and radiocarbon measurements. J Archaeol Sci 26:687-695

Lachiri N (1993) La vida cotidiana de las mujeres en el al-Ándalus y su reflejo en las fuentes literarias. In: del Moral C (ed) Árabes, judías y cristianas: Mujeres en la Europa medieval. Madrid, pp 103-122

Larsen CS (2002) Bioarchaeology: The Lives and Lifestyles of Past People. Journal of Archaeological Research, 10 (2). Kluwer Academic Publishers-Plenum Publishers:119-166 Accessed 23 March 2019

Linderholm A, Jonson CH, Svensk O, Lidén K (2008) Diet and status in Birka: stable isotopes and grave goods compared. Antiquity 82: 446-461. https://doi.org/10.1017/S0003598X00096939

Lewicka P (2011) Food and Foodways of Medieval Cairenes: Aspects of Life in an Islamic Metropolis of the Eastern Mediterranean. Brill, Leiden/Boston

Liversidge HM, Molleson TI (1999) Developing permanent tooth length as an estimate of age. J Forensic Sci 44:917-920

Liversidge HM, Dean MC, Molleson TI (1993) Increasing human tooth length between birth and 5.4 years. Am J Phys Anthropol 90:307313

Longin R (1971) New method of collagen extraction for radiocarbon dating. Nature 230:241-242

López-Costas O (2012) Antropología de los restos óseos humanos de Galicia: estudio de la población romana y medieval gallega, vol 2013. Universidad de Granada, Granada, p 553

López-Costas O, Müldner G (2016) Fringes of the empire: diet and cultural change at the Roman to post-Roman transition in NW Iberia. Am J Phys Anthropol 161:141-154

Lovejoy CO, Meindl RS, Pryzbeck TR, Mensforth RP (1985) Chronological metamorphosis of the auricular surface of the ilium: a new method for the determination of adult skeletal age at death. Am J Phys Anthropol 68:15-28

Lubritto C, García-Collado MI, Ricci P, Altieri S, Sirignano C, Quirós Castillo JA (2017) New dietary evidence on medieval rural communities of the Basque Country (Spain) and its surroundings from carbon and nitrogen stable isotope analyses: social insights, diachronic changes and geographic comparison. Int J Osteoarchaeol 27:984-1002

Marín M (2000) Mujeres en al-Andalus. In: del Moral C (ed) Árabes, judías y cristianas. Consejo superior de investigaciones científicas Madrid, Madrid, pp 35-52

Martins SC (2013) Estudo arqueofaunistico do Castelo de Salir (Loule). Contribuicao para o conhecimento da dieta alimentar Islamica. Mestrado em Arqueologia. Faculdade de Ciencias Humanas e Sociais

Marques AHR d O (1962) Introdução à história da agricultura em Portugal: a questão cerealífera durante a Idade Média. Cosmos, Lisboa

Marques AHR de O (1987) Portugal na crise dos séculos XIV e XV. Editorial Presença, Lisboa

Martínez-Jarreta B, Sosa C, Laliena C, Budowle B, Hedges REM (2017) Stable isotope and radiocarbon dating of the remains of the Medieval Royal House of Aragon (Spain) shed light on their diets, life histories and identities. Archaeometry. 60:366-382. https://doi. org/10.1111/arcm.12307

Matos VMJ (2009) O diagnóstico retrospectivo da lepra: complementaridade clínica e paleopatológica no arquivo médico do Hospital-Colónia Rovisco Pais (século XX, Tocha, Portugal) e na colecção de esqueletos da leprosaria medieval de St. Jorgen's (Odense, Dinamarca). PhD Dissertation. University of Coimbra 
Matos V, Santos AL (2006) On the trail of pulmonary tuberculosis based on rib lesions: results from the human identified skeletal collection from the Museu Bocage (Lisbon, Portugal). Am J Phys Anthropol 130:190-200

Mays S (1995) The relationship between Harris lines and other aspects of skeletal development in adults and juveniles. J Archaeol Sci 22:511520

Mays S (2013) A discussion of some recent methodological developments in the osteoarchaeology of childhood. Childhood in the past $6: 4-21$

Mcllvaine BK (2015) Implications of reappraising the iron-deficiency anemia hypothesis. Int J Osteoarchaeol 25:997-1000

Melo S (2014) Lisboa islâmica. Contributos para o estudo do sistema defensivo. Al-Madan 18:42-52

Millard AR (2000) A model for the effect of weaning on nitrogen isotope ratios in humans. In: Goodfriend GA, Collins MJ, Fogel M, Macko SA, Wehmiller JF (eds) Perspectives in amino acid and protein geochemistry. Oxford University Press, Oxford, pp 51-59

Milner N, Craig OE, Bailey GN, Pedersen K, Andersen SH (2004) Something fishy in the Neolithic? A re-evaluation of stable isotope analysis of Mesolithic and Neolithic coastal populations. Antiquity 78(299):9-22

Montanari M (1999) Production structures and food systems in the early middle ages. In: Flandrin J-L, Montanari M (eds) Food, a culinary history from antiquity to the present. Columbia University Press, New York, pp 168-177

Manuppella G (1987) Livro de cozinha da Infanta D. Maria: códice português I.E. 33 da Biblioteca Nacional de Nápoles. Imprensa Nacional, Lisboa

Morales Muñiz A (1993) Estudio faunístico del yacimiento islámico de Mértola: los mamíferos. Arqueologia Medieval 2:263-271

Moreno-García (2008) Estudo arqueofaunístico de dois silos islâmicos no Castelo de Sao Jorge, Lisboa

Moreno-García M, Davis S (2001) Estudio de las asociaciones faunísticas recuperadas en Alcácer do Sal, Convento de São Francisco, Santarém y Sé de Lisboa. In: de Cultura y Patrimonio EC, da Cultura PM, do Património Arquitectónico IP (eds) Garb-Sítios Islâmicos do Sul Peninsular. IPPAR, Lisboa, pp 231-255

Moreno-García M, Gabriel S (2001) Faunal remains from 3 Islamic contexts at Núcleo arqueológico da Rua dos Correeiros, Lisbon. Trabalhos do CIPA 20:1-30

Moreno-García M, Pimenta CM (2012) Ossos no lixo : contributo arqueozoológico para o estudo da alimentação na Mértola islâmica. In: Gómez Martínez S (ed) Memória dos sabores do Mediterrâneo. Campo Arqueológico de Mértola, pp 153-176

Moynihan P, Petersen PE (2004) Diet, nutrition and the prevention of dental diseases. Public Health Nutri 7(1A):201-226

Mundorff-Shrestha SA et al (1994) Cariogenic potential of foods. II. Relationship of food composition, plaque microbial counts, and salivary parameters to caries in the rat model. Caries Res 28(2):106115

Müldner G, Richards MP (2007) Diet and diversity at later medieval Fishergate: the isotopic evidence. Am J Phys Anthropol 134(2): $162-174$

Nasrallah N (2007) Annals of the caliphs' kitchens: Ibn Sayyar AlWarraq's tenth-century Baghdadi cookbook. Brill, Leiden

Müldner G, Montgomery J, Cook G, et al (2009) Isotopes and individuals: diet and mobility among the medieval Bishops of Whithorn. Antiquity 83:1119-1133. https://doi.org/10.1017/ S0003598X00099403

Nehlich O, Fuller BT, Márquez-Grant N, Richards MP (2012) Investigation of diachronic dietary patterns on the islands of Ibiza and Formentera, Spain: evidence from sulfur stable isotope ratio analysis. Am J Phys Anthropol 149:115-124

Oliveira AR (2007) A criança na sociedade medieval portuguesa. Editorial Teorema, Lisboa
Ortner DJ (2003) Identification of pathological conditions in human skeletal remains. Academic Press, Washington, DC

Oxenham MF, Cavill I (2010) Porotic hyperostosis and cribra orbitalia: the erythropoietic response to iron-deficiency anaemia. Anthropol Sci 118(3):199-200

Pellat C, Sourdel-Thomine J, Elwell-Sutton LP, Boratav PN (2012) Hayawān. In: Encyclopaedia of Islam, Second Edition. Brill, Leiden/Boston

Pereira V (2013) Das faunas às populações-reflexos islâmicos do Castelo de Paderne. Techne 1:67-73

Pérez Ordóñez A (2009) Algunos apuntes sobre las mujeres en la casa andalusí. In: Espinosa MC, López Cordero JA (eds) Congreso virtual sobre historia de las mujeres (15 al 31 de octubre de 2009) Asociación de Amigos del Archivo Histórico Diocesano de Jaén, Jaen, pp 1-23.

Picard C (2000) Le Portugal musulman VIIIème-XIIIème siècle : L'Occident d'al-Andalus sous domination islamique. Maisonneuve \& Larose, Paris

Pickard C, Girdwood L-K, Kranioti E et al (2017) Isotopic evidence for dietary diversity at the mediaeval Islamic necropolis of Can Fonoll (10th to 13th centuries CE), Ibiza, Spain. J Archaeol Sci Rep 13:110

Powell ML (1985) The analysis of dental wear and caries for dietary reconstruction. In: Gilbert RI, Mielke LJH (eds) The analysis of prehistoric diets. Academic Press, New York, pp 307-338

Powell JF (1995) Dental variation and biological affinity among middle Holocene human populations in North America. PhD, Texas A\&M University

Queiroz PF (1999) Estudos de Arqueobotanica no Convento de Sao Francisco de Santarem. In: Garb - Sítios Islâmicos do Sul Peninsular. IPPAR, pp 89-117

Queiroz PF, Mateus JE (2012) Às plantas no quotidiano do mundo islâmico. Vestígios arqueobotânicos do sul de Portugal. In: Gomez Martinez S (ed) Memória dos sabores do Mediterrâneo. Campo Arqueológico / Centro de Estudos Arqueológicos das Universidades de Coimbra e Porto, Mértola, pp 177-200

Rei A (2017) Elementos vegetais na alimentação de al-Usbuna, entre os seculos X e XII. In: Senna Martinez JC et al (eds) Diz-me o que comes... alimentação antes e depois da cidade. Fragmentos de Arqueologia de Lisboa. 1. ACDPRINT, S.A., Lisboa, pp 67-75

Reitsema LJ, Vercellotti G (2012) Stable isotope evidence for sex- and status-based variations in diet and life history at medieval Trino Vercellese, Italy. Am J Phys Anthropol 148(4):589-600

Reitz EJ, Speller C, McGrath K, Alexander M (2016) A sixteenth-century turkey (Meleagris gallopavo) from Puerto Real, Hispaniola. J Archaeol Sci Rep 10:640-646. https://doi.org/10.1016/j.jasrep. 2016.05.050

Richards MP, Mays S, Fuller BT (2002) Stable carbon and nitrogen isotope values of bone and teeth reflect weaning age at the Medieval Wharram Percy site, Yorkshire, UK. Am J Phys Anthropol 119:205-210. https://doi.org/10.1002/ajpa.10124

Ritzman TB, Baker BJ, Schwartz GT (2008) A fine line: comparison of methods for estimating ages of linear enamel hypoplasia formation. Am J Phys Anthropol 135:348-361

Robledo B, Trancho GJ (2003) Patología oral en la población HispanoMusulmana de Xarea (Almería). In: Campo Martín M, Robles Rodríguez FJ (eds) ¿Dónde estamos? pasado, presente y futuro de la Paleopatología: actas del VI Congreso Nacional de Paleopatología (Madrid, 13 al 16 de septiembre de 2001). Asociación Española de Paleopatología, Madrid, pp 375-385

Robles FJ, González A, García C (1996) Indicadores de estrés en la población hispano-musulmana de San Nicolás (Murcia, s. XI a XIII). In: Perez-Perez A (ed) Salud, Enfermedad y Muerte en el Pasado. Consecuencias biológicas del estrés y la patología. Actas del III Congreso Nacional de Paleopatología. Fundación Uriach 1838, Barcelona, pp 18-12 
Rosenberger B (1999) Arab cuisine and its contribution to European culture. In: Flandrin J-L, Montanari M (eds) Food: a culinary history from antiquity to the present. Columbia University Press, New York, pp 207-223

Salazar-García DC, Richards MP, Nehlich O, Henry AG (2014) Dental calculus is not equivalent to bone collagen for isotope analysis: a comparison between carbon and nitrogen stable isotope analysis of bulk dental calculus, bone and dentine collagen from same individuals from the medieval site of El Raval (Alicante, Spain). J Archaeol Sci 47:70-77

Salazar-García DC, Romero A, García-Borja P et al (2016) A combined dietary approach using isotope and dental buccal-microwear analysis of human remains from the Neolithic, Roman and Medieval periods from the archaeological site of Tossal de les Basses (Alicante, Spain). J Archaeol Sci Rep 6:610-619

Saragoça P, Maurer A-F, Šoberl L et al (2016) Stable isotope and multianalytical investigation of Monte da Cegonha: a late antiquity population in southern Portugal. J Archaeol Sci Rep 9:728-742

Scheuer L, Black S, Schaefer M (2009) Juvenile osteology. Elsevier, London

Schwarcz HP, Dupras TL, Fairgrieve SI (1999) $15 \mathrm{~N}$ enrichment in the Sahara: in search of a global relationship. J Archaeol Sci 26(6):629 636

Shahar S (1990) Childhood in the middle ages. Taylor \& Francis, New York

Silva AM (1995) Sex assessment using the calcaneus and talus. Antropol Port 13:107-119

Silva R (2014) "Monumentos e museografia: dois espaços museológicos no Castelo de São Jorge, em Lisboa", integrated master thesis in architecture. Instituto Superior Técnico, Universidade de Lisboa, Lisbon

Simoons FJ (1961) Eat not this flesh. Food avoidances in the Old World. University of Wisconsin Press, Madison

Smith BH (1984) Patterns of molar wear in huntergatherers and agriculturalists. Am J Phys Anthropol 63:39-56
Stuart-Macadam P (1985) Porothic hyperostosis: representative of a childhood condition. Am J Phys Anthropol 66:391-398

Torres C (1994) Lisboa Muçulmana e o seu Território. Lisboa Subterrânea, Catálogo da exposição, Lisboa, Museu Nacional de Arqueologia, Lisboa, pp 81-86

Valente MJ, Marques A (2017) Alimentação mudéjar em Lisboa: dados preliminares sobre a zooarqueologia do Largo da Severa (Mouraria, Lisboa). In: Senna Martinez JC et al (eds) Diz-me o que comes... alimentação antes e depois da cidade. Fragmentos de Arqueologia de Lisboa. 1. ACDPRINT, S.A., Lisboa

Visser M (2012) The rituals of dinner: the origins, evolution, eccentricities, and meaning of table manners. HarperCollins, Canada

Walker PL (1986) Porotic hyperostosis in a marine-dependent California Indian population. Am J Phys Anthropol 69:345-354

Walker PL (2009) The causes of porotic hyperostosis and cribra orbitalia: a reappraisal of the iron-deficiency-anemia hypothesis. Am J Phys Anthropol 139:109-125

Walrath DE, Turnern P, Bruzek J (2004) Reliability test of the visual assessment of cranial traits for sex determination. Am J Phys Anthropol 125:132-137

Winer RL (2008) Conscripting the breast: lactation, slavery and salvation in the realms of Aragon and kingdom of Majorca, c. 1250-1300. J Mediev Hist 34(2):164-184

Wood JW, Milner GR, Harpending HC, Weiss KM, Cohen MN, Eisenberg LE, Hutchinson DL, Jankauskas R, ACEesnys G, Katzenberg MA, Lukacs JR, JW MG, Roth EA, Ubelaker DH, Wilkinson RG (1992) The osteological paradox: problems of inferring prehistoric health from skeletal samples [and comments and reply]. Curr Anthropol 33:343-370

Publisher's note Springer Nature remains neutral with regard to jurisdictional claims in published maps and institutional affiliations. 